\title{
opes $\partial$ Access
}

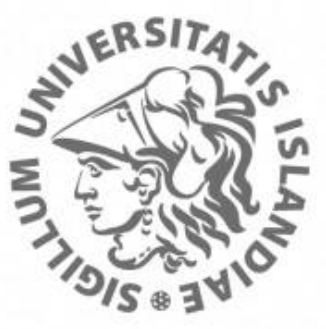

Bopin vísindl

This is not the published version of the article / Petta er ekki útgefna útgáfa greinarinnar

Author(s)/Höf.: $\quad$ J L Till, N Nowaczyk

Title/Titill: $\quad$ Authigenic magnetite formation from goethite and hematite and chemical remanent magnetization acquisition

Year/Útgáfuár: $\quad 2018$

Version/Útgáfa: $\quad$ Post-print (lokagerđ höfundar)

\section{Please cite the original version:}

\section{Vinsamlega vísið til útgefnu greinarinnar:}

Till, J. L., \& Nowaczyk, N. (2018). Authigenic magnetite formation from goethite and hematite and chemical remanent magnetization acquisition. Geophysical Journal International, 213(3), 1818-1831. doi:10.1093/gii/ggy083

Rights/Réttur: $\quad$ (c) 2018 The Author(s) Published by Oxford University Press on behalf of the Royal Astronomical Society 


\title{
Authigenic magnetite formation from goethite and hematite and chemical remanent magnetization acquisition
}

\author{
J.L. Till ${ }^{1,2 \star}$, N. Nowaczyk ${ }^{1}$ \\ 1: Deutsches GeoForschungsZentrum GFZ Potsdam, Telegrafenberg, 14473 Potsdam, \\ Germany \\ 2: University of Iceland, Institute of Earth Sciences, Askja, Sturlugata 7, 101 Reykjavik, Iceland
}

20 February 2018

\section{SUMMARY}

The iron oxyhydroxide goethite is unstable at elevated temperatures and can transform to magnetite under reducing conditions. In this study, various heating experiments were conducted to simulate Fe-mineral transformations during pyrogenic or burial diagenesis alteration in the presence of organic matter. Thermomagnetic measurements, capsule heating experiments and thermo-chemical remanence acquisition measurements were performed to determine the effect of organic carbon additions on samples containing synthetic microcrystalline goethite, microcrystalline hematite or nanocrystalline goethite. Changes in magnetic properties with heating were monitored to characterize the magnetic behavior of secondary magnetite and hematite formed during the experiments. Authigenic magnetite formed in all samples containing organic C, while goethite heated without organic $\mathrm{C}$ altered to poorly crystalline pseudomorphic hematite. The concentration of organic matter was found to have little influence on the rate or extent of reaction or on the characteristics of the secondary phases. Authigenic magnetite formed from microcrystalline goethite and hematite dominantly behaves as interacting single- 
domain particles, while nanophase goethite alters to a mixture of small single-domain and superparamagnetic magnetite. Authigenic magnetite and hematite both acquire a stable thermo-chemical remanence on heating to temperatures between 350 and $600^{\circ} \mathrm{C}$, although the remanence intensity acquired below $500^{\circ} \mathrm{C}$ is much weaker than that at higher temperatures. Reductive transformation of fine-grained goethite or hematite is therefore a potential pathway for the production of authigenic magnetite and the generation of stable chemical remanence that may be responsible for remagnetization in organic matter-bearing sedimentary rocks.

Key words: iron oxyhydroxides - magnetic nanoparticles - authigenic magnetite mineral alteration - chemical remanent magnetization.

\section{INTRODUCTION}

Among the various iron oxide phases found in surface environments, goethite and hematite are the most abundant due to their greater stability under oxic conditions (Schwertmann \& Cornell 2007). Because they form through weathering processes at low temperatures, these minerals typically occur as very fine, sub-micron particles in the clay-size fraction of soils and sediments. Goethite $(\alpha-\mathrm{FeOOH})$ is particularly widespread in soils, dust, and lake and marine sediments and is the dominant Fe-oxide phase in many soils in temperate zones, while hematite is more prevalent in low-latitude soils (Schwertmann \& Cornell 2007). The dehydroxylation transformation of goethite to psuedomorphic hematite $\left(\alpha-\mathrm{Fe}_{2} \mathrm{O}_{3}\right)$ was recognized at least as early as the work of Goldsztaub (1931), and was followed by numerous investigations that determined the topotactic structural relationships between the two phases and the nano-crystalline nature of the secondary hematite (Rooksby 1951; Francombe \& Rooksby 1959; Lima-de Faria 1963). Goethite dehydroxylation begins at temperatures around $150^{\circ} \mathrm{C}$ (Cudennec \& Lecerf 2005), and in addition to secondary hematite formation, some studies have detected the presence of magnetite in dehydroxylated goethite (Lima-de Faria 1967; Goss 1987; Ibrahim et al. 1994; Lowrie \& Heller 1982). Various rock magnetic studies have 
also observed the transformation of both goethite and hematite to magnetite during laboratory heating experiments (Dekkers 1990; Özdemir \& Dunlop 2000; Hanesch et al. 2006).

More recent work by Till et al. $(2015,2017)$ demonstrated that nanocrystalline goethite can rapidly transform to fine-grained magnetite under reducing conditions at moderately elevated temperatures $\left(\mathrm{T}=210-270^{\circ} \mathrm{C}\right)$. These studies identified a two-step process involving dehydroxylation of goethite to nano-hematite, and subsequent rapid reduction and recrystallization of intermediate nano-hematite to fine-grained magnetite. Reductive transformation of hematite to magnetite has been less extensively studied, but has been observed in laboratory thermomagnetic measurements on hematite-bearing sediments (e.g. Deng et al. 2004). Hematite reduction may occur due to heating in the presence of organic carbon, as in experiments by Hanesch et al. (2006), but was also demonstrated by Zhang et al. (2012) to result from the presence of $\mathrm{Fe}^{2+}$-bearing chlorite during anoxic heating up to $700^{\circ} \mathrm{C}$.

Reductive thermal alteration of goethite to magnetite in natural settings may also occur when it is heated in the presence of organic matter (Schwertmann \& Fechter 1984). Many examples of pyrogenic alteration of goethite to magnetite or maghemite and associated magnetic enhancement have been reported for soils affected by wildfires (Anand \& Gilkes 1987; Ketterings et al. 2000; Grogan et al. 2003; Clement et al. 2011), in which burning vegetation and leaf litter provide a reducing atmosphere that promotes the formation of magnetite. Similarly, Nørnberg et al. (2009) demonstrated the formation of hematite and maghemite in a goethite-bearing soil subjected to an experimental forest fire. The soil used in their experiment also contained organic matter that acted as the reducing agent for the hematite produced by goethite dehydroxylation. Following fire events, erosion may subsequently transport pyrogenic magnetite to sedimentary settings such as lakes and continental shelves through runoff or aeolian processes (Whicker et al. 2002; Smith et al. 2013).

Goethite occurs in marine sediments as a detrital phase, but can also form in the sediment column by oxidation of dissolved Fe(II) (van der Zee et al. 2003) or it can replace primary pyrite (Heller 1978). Reductive diagenetic alteration (Rude \& Aller 1989; Abrajevitch et al. 2009) may produce elevated temperatures and conditions that promote authigenic 
magnetite formation from sedimentary goethite in deeply buried organic-bearing metasediments. If in-situ growth of magnetite occurs below its Curie temperature $\left(T_{C}\right)$ of around $580^{\circ} \mathrm{C}$ (Hunt et al. 1995), it will acquire a chemical remanent magnetization (CRM) that may greatly alter the overall remanence behavior and paleomagnetic signature of the host rock or sediment. However the generation of CRM in authigenic magnetite derived from goethite transformation has not yet been explored in either experimental or field studies.

This paper investigates the goethite transformation process in the presence of organic matter to simulate processes such as deep burial diagenesis, low-grade metamorphism of sediments or soil alteration during wildfire. The magnetic properties and particle morphologies of the alteration products were characterized as a function of goethite grain size, heating temperature, time and organic matter concentration. Because the transformation of goethite to magnetite occurs via an intermediate hematite phase, experiments were also carried out on fine-grained hematite and poorly crystalline hematite aggregates (pre-heated, dehydroxylated goethite) for comparison. To better simulate natural conditions of thermal mineral alteration, goethite and hematite were heated with a source of organic carbon rather than a gas atmosphere as used in previous experiments. In addition, experiments of thermochemical remanent magnetization (TCRM) acquisition were conducted and the remanence behavior of the alteration products was characterized.

\section{METHODS}

\subsection{Starting materials}

Synthetic fine-grained micro-goethite (Bayferrox 930) and synthetic micro-hematite (Bayferrox 110) were obtained as commercially available powdered pigments. The micro-goethite has elongated to acicular particle shapes with average dimensions of 600 by $100 \mathrm{~nm}$ (Figure 1a), while the micro-hematite particles are equant with an average diameter of around 90 $\mathrm{nm}$ (Figure 1b). According to the manufacturer specifications, the purities of the goethite and hematite pigments are 99.4 and 94.1\%, respectively. Nano-goethite was synthesized according to the protocol of Schwertmann \& Cornell (2007) in a similar manner as that 
described by Till et al. (2015). Briefly, a mixture of $\mathrm{FeCl}_{2} \cdot 4 \mathrm{H}_{2} \mathrm{O}$ and $\mathrm{NaHCO}_{3}$ was stirred and slowly oxidized over several days. This procedure precipitated elongated oriented aggregates of nanocrystalline goethite, with aggregate lengths and widths around $15 \mathrm{~nm}$ by 60 $\mathrm{nm}$, composed of small crystallites approximately $5 \mathrm{~nm}$ wide (Figure 1c). The nano-goethite aggregates contain abundant defects in the form of low-angle grain boundaries and small voids.

\subsection{Heating experiments and characterization}

All experiments and sample characterization were performed at the Deutsches GeoForschungs Zentrum (GFZ Potsdam) and the University of Iceland. Three types of heating experiments were performed using finely ground sugar as the organic carbon source, which was thoroughly mixed with the goethite and hematite samples in various proportions. First, a series of thermomagnetic measurements were performed in which bulk susceptibility was measured as a function of temperature during heating and cooling of goethite and hematite samples with and without organic carbon up to $700^{\circ} \mathrm{C}$. For experiments with organic C, the mineral powders were mixed with added sugar and enclosed in narrow $\mathrm{Cu}$ foil packets. These experiments were performed in an Agico Kappabridge MFK1 susceptibility meter without an external gas flow. Secondly, a series of capsule heating experiments was performed on goethite and hematite samples mixed with calcite powder and various proportions of sugar. Initial organic $\mathrm{C}$ to mineral ratios were either $3: 1$ or 1:2 by weight. The mixed sample powders were enclosed in small $\mathrm{Cu}$ or $\mathrm{Al}$ foil capsules and heated in a series of experiments in a horizontal furnace with a flowing Ar gas atmosphere between temperatures of 250 and $350^{\circ} \mathrm{C}$ for durations of 3 to $64 \mathrm{~h}$. The conditions and sample compositions for each experiment are listed in Table 1. The transformation of goethite and hematite to magnetite was monitored by measuring the hysteresis properties of each sample after heating. Distinct changes in sample color were also noted after each experiment. All thermomagnetic experiments containing organic $\mathrm{C}$ were black in color after heating. The final colors of the capsule heating 
experiment samples ranged from pink/red to tan/brown to grey/black, depending on the extent of transformation and concentration of Fe minerals in the calcite matrix.

The grain size and morphology of the starting materials and altered samples were characterized with transmission electron microscopy (TEM) at $200 \mathrm{kV}$ accelerating voltage on a Tecnai microscope equipped with a field emission gun, a high-angle annular dark field (HAADF) detector, and energy dispersive spectroscopy. Room-temperature magnetic hysteresis properties of the starting materials and altered samples were measured on a Princeton Instruments alternating gradient magnetometer (AGM). To examine the detailed distribution of magnetic domain states and degree of magnetostatic interactions in the transformed samples, first-order reversal curve (FORC) measurements were obtained for representative samples with the AGM before and after heating. FORC and hysteresis measurements were made using a saturating field of $1 \mathrm{~T}$, and an averaging time of $0.1 \mathrm{~s}$. The number of FORCs made per measurement varied between 70 and 150 with field increments between 1.2 and $2.8 \mathrm{mT}$. FORC diagrams were processed using the FORCinel software package (Harrison \& Feinberg 2008).

\subsection{TCRM acquisition experiments}

A third series of experiments was performed to investigate thermo-chemical remanence acquisition in authigenic magnetite and hematite formed during reductive alteration of the starting materials. Samples were prepared by mixing hematite or goethite with an organic carbon source (sugar) in a 1:2 ratio by weight, which were then dispersed in a fine-grained calcite matrix with an initial Fe-mineral content of 2 or 5 wt\%. These powders were thoroughly ground in an agate mortar to distribute the iron oxides as uniformly as possible. The powders were then packed into ceramic cylinders with an internal volume of approximately $2 \mathrm{~cm}^{3}$ fabricated from alumina tubing. Disk-shaped alumina end caps were sealed using a high-temperature alumina-based cement (CeramaBond) that was allowed to cure overnight. To compare the initial low-field remanence of the samples with the measurements of TCRM strength, an anhysteretic remanent magnetization (ARM) given in a bias field of $0.05 \mathrm{mT}$ 
was measured for all samples, which was then AF demagnetized in a maximum field of 200 $\mathrm{mT}$ prior to heating. TCRM acquisition was performed by placing the samples in the sealed ceramic holders in a Magnetic Measurements paleomagnetic furnace with field control using heating rates of approximately 50\% $\mathrm{min}$ at temperature steps of 300, 350, 400, 450, 500, 550, and $600^{\circ} \mathrm{C}$. Samples were held at the target temperature for 15 to $60 \mathrm{~min}$, using longer hold times at lower temperatures. A field of $50 \mu \mathrm{T}$ was applied in the furnace approximately along the cylindrical sample axes during heating and cooling. Arbitrary coordinates were assigned to the samples so that the direction of acquired magnetization was along the $+\mathrm{Z}$ direction. Remanence values were measured on a $2 \mathrm{G}$ cryogenic rock magnetometer immediately after each heating step to minimize any viscous magnetization effects (Supporting Information, Table S1). A 10-step AF demagnetization sequence up to $100 \mathrm{mT}$ was performed after selected heating steps to characterize the direction and stability of the magnetization vector (Supporting Information, Table S2). Various control samples were also heated and measured alongside the samples containing mineral + organic $\mathrm{C}$ mixtures, including a sample of only calcite powder and organic $\mathrm{C}(5 \mathrm{wt} \%)$ and samples containing only goethite or hematite dispersed in calcite without organic C. The former allowed the background remanence values of the calcite-organic C matrix and ceramic holder to be determined at each heating step, which were typically small compared with those of the oxide-containing samples.

\section{RESULTS}

\subsection{Thermomagnetic experiments}

\subsubsection{Thermal behavior of goethite and hematite}

The temperature-dependent susceptibility curve for micro-hematite (Figure 2a) exhibits a steep drop in susceptibility at around $690^{\circ} \mathrm{C}$, which is slightly higher than the nominal hematite Néel temperature $\left(\mathrm{T}_{N}\right)$ of $675^{\circ} \mathrm{C}$ (Hunt et al. 1995). A small reversible drop around $625^{\circ} \mathrm{C}$ in the micro-hematite curves suggests that the hematite powder contains

a small amount of a lower- $\mathrm{T}_{c}$ impurity, possibly maghemite (Özdemir \& Banerjee 1984). 
Dehydroxylation of micro-goethite to hematite is marked by a gradual decrease in susceptibility between 300 and $400^{\circ} \mathrm{C}$ (Figure 2b), which was also noted by Strangway et al. (1968) and Dekkers (1990). This is followed by a prominent Hopkinson peak just below the $\mathrm{T}_{N}$ of hematite. A smaller non-reversible drop around $550^{\circ} \mathrm{C}$ on heating suggests the formation of a transient magnetite-like phase, such as that observed during heating experiments on goethite by Özdemir \& Dunlop (2000). A similar ferromagnetic phase was observed by De Boer \& Dekkers (2001) during heating of hematite produced from a ferrihydrite precursor. Although nano-goethite begins to dehydroxylate at around $200^{\circ} \mathrm{C}$ (Till et al. 2015), this change is not evident in the susceptibility curve on heating (Figure 2c). Nano-goethite displays a less pronounced decrease in susceptibility around $675^{\circ} \mathrm{C}$, also due to secondary hematite formation. As in the experiments of Hanesch et al. (2006), a transition in susceptibility around the goethite $\mathrm{T}_{N}$ of $120^{\circ} \mathrm{C}$ is not apparent in either goethite sample. No evidence for any additional Fe-oxide phases such as lepidocrocite or ferrihydrite can be seen in the thermomagnetic curves for the starting materials. Lepidocrocite transforms to maghemite around $250^{\circ}$ upon heating in air, which produces an irreversible increase in susceptibility upon heating, and ferrihydrite transforms to hematite at lower temperatures than does goethite (Hanesch et al. 2006). The absence of such features indicates that the goethite samples are relatively free of impurities.

\subsubsection{Thermal behavior of organic C-bearing samples}

Thermomagnetic curves of all goethite and hematite samples heated with organic carbon (sugar) exhibit large, partly irreversible increases in susceptibility during heating (Figure 2df). The non-reversible portion of the susceptibility increase represented by the elevated cooling curves is caused by conversion of the ferric oxides to nearly pure magnetite, as indicated by Curie temperatures around $580^{\circ} \mathrm{C}$ in both the heating and cooling curves. The temperature at which susceptibility begins to increase is around $370^{\circ} \mathrm{C}$ for nano-goethite, $400^{\circ} \mathrm{C}$ for micro-goethite, and $420^{\circ} \mathrm{C}$ for micro-hematite. The thermomagnetic experiments revealed several other features of the transformation process. Previously heated micro-goethite that 
was dehydrated to nano-hematite (Figure 2g) behaves nearly identically to micro-goethite heated with organic carbon (Figure 2e), supporting the interpretation that magnetite formation proceeds by a two-step process involving first dehydroxylation to hematite, then reduction and recrystallization of nano-hematite to magnetite, as postulated by Till et al. (2015). Micro-goethite samples containing either $10 \%$ carbon or $60 \%$ carbon exhibited very similar thermomagnetic curves (Figure 2h), which suggests that the relative amount of organic carbon does not significantly influence the minimum temperature or the extent of transformation to magnetite in these samples.

Partial heating of micro-goethite with organic carbon up to $400^{\circ} \mathrm{C}$ followed by cooling to room temperature and repeated heating to $700^{\circ} \mathrm{C}$ produced nearly identical values between during the first cooling curve and the subsequent reheating curve (Figure 2i). Based on this experiment, the magnetite produced at intermediate temperatures appears to be thermally stable up to $700^{\circ} \mathrm{C}$. By contrast, Hanesch et al. (2006) found that the magnetite formed from goethite became oxidized back to hematite during the course of their thermomagnetic measurements. In the current experiments, the samples are contained in $\mathrm{Cu}$ foil, which limits their exposure to oxygen during heating and prevents oxidation to hematite. The magnetite produced by heating micro-goethite and micro-hematite with organic $\mathrm{C}$ exhibits sharp, reversible susceptibility peaks in the thermomagnetic curves. These features are due to the Hopkinson effect, which is typically most pronounced in single-domain particles as a result of superparamagnetic (SP) behavior above the particle unblocking temperature and below the Curie temperature (Pfeiffer \& Schüppel 1994; Van Oorschot \& Dekkers 1999; Dunlop 2014). The sharpness of the Hopkinson peaks indicates that the magnetite particles all have similarly high blocking temperatures and a narrow grain size distribution that results from the uniform grain size of the starting goethite and hematite particles.

The thermomagnetic behavior of nano-goethite heated with organic $\mathrm{C}$ contrasts with those of the micro-goethite and hematite samples. The curve in Figure $2 \mathrm{f}$ displays a rapid increase on heating followed by a gradual decrease in susceptibility with a Curie temperature of about $580^{\circ} \mathrm{C}$, creating a broad asymmetric peak that is not reversible on cooling. Unlike in 
natural materials, where smoothing of the Curie point occurs due to either contributions from paramagnetic minerals or compositional inhomogeneities (Fabian et al. 2013), the gradual decrease in susceptibility here probably reflects the size-dependent distribution of ordering temperatures in ultrafine magnetite particles produced during heating. Significant reductions in $T_{c}$ for pure magnetite particles less than $20 \mathrm{~nm}$ in diameter have been experimentally demonstrated (Sadeh et al. 2000), an effect that arises from weakened exchange coupling due to greater numbers of incompletely coordinated ions at the particle surface as the specific surface area increases (Shcherbakov et al. 2012). Based on the SP-like characteristics of the hysteresis properties for altered nano-goethite samples (see below), the higher values in the cooling curve are interpreted to result from grain growth and coarsening of some SP-sized particles of magnetite into the SD size range.

\subsection{Capsule heating experiment results}

\subsubsection{Hysteresis properties}

Hysteresis loops for goethite and hematite starting materials are displayed in Figure 3a. A hysteresis loop is also shown for dehydrated micro-goethite from sample GA-16F, which was heated without organic carbon and contains only fine-grained secondary pseudomorphic hematite. Both goethite samples have very low room-temperature remanent magnetization $\left(J_{R}\right)$ and linear high field slopes. The absence of room-temperature remanence is typical for nanocrystalline goethite (Till et al. 2015), which often has sub-room-temperature ordering temperatures (Guyodo et al. 2003). Although several previous studies have noted that natu-

ral and synthetic microcrystalline goethite is characterized by very high coercivity $\left(H_{C}\right)$ and is difficult to saturate in typical laboratory fields (Roberts et al. 2006), the coercivity of the micro-goethite measured here is relatively small, as is that of the hematite produced from dehydrated micro-goethite. Micro-hematite samples have wasp-waisted loops signifying minor contributions from an additional ferromagnetic phase, which is inferred to be maghemite based on the $\mathrm{T}_{C}$ of 625 observed in the thermomagnetic curve (Figure 2a). Assuming an $M_{s}$ value of $66 \mathrm{Am}^{2} / \mathrm{kg}$ for maghemite, the starting micro-hematite contains less than $0.7 \%$ 
maghemite based on the measured Ms of $0.421 \mathrm{Am}^{2} / \mathrm{kg}$. This is consistent with findings from Frank \& Nowaczyk (2008), who concluded that wasp-waisted loops were only observed for mixtures with hematite-magnetite ratios over 99.5. It is likely that the maximum field of $1 \mathrm{~T}$ used in hysteresis measurements was not sufficient to magnetically saturate either the micro-hematite or micro-goethite. Thee measured hysteresis parameters for these phases are thus not true saturation values, however they serve as a comparison for the thermo-reduced samples, which have distinct properties from those of the starting materials.

Hysteresis loops for representative capsule heating experiments initially containing goethite or hematite and organic C ("thermo-reduced" samples) are shown in Figure 3b. Hysteresis parameters for all capsule heating experiments after high-field slope correction are reported in Table 1 . The slope-corrected saturation magnetization $\left(J_{S}\right)$ values were normalized by the initial mass of the oxide phase in the starting powder mixture and by a nominal $J_{S}$ value of $92 \mathrm{Am}^{2} / \mathrm{kg}$ for pure magnetite to provide a minimum estimate of the percent conversion of goethite or hematite to magnetite. Thermoreduced micro-hematite and micro-goethite exhibit hysteresis loops typical of single-domain (SD) magnetite, including moderate coercivities and remanence ratios with saturation by $300 \mathrm{mT}$. Weakly reacted hematite samples, such as GA-16C (Figure 3b) retain the wasp-waisted shape of the starting material, reflecting a mixture of high-coercivity hematite and a small amount of low-coercivity magnetite. Although the transformed micro-goethite capsule samples also contain a mixture of finegrained secondary hematite and magnetite, the secondary hematite has a bulk coercivity similar to that of the secondary magnetite, so that the mixture of phases is not apparent in the shape of the hysteresis loops.

Loops for thermo-reduced nano-goethite are comparatively narrow with very low ratios of saturation remanence $\left(J_{R}\right)$ to $J_{S}$ and low coercivities. These properties are consistent with a high proportion of SP magnetite mixed with small SD particles (Till et al. 2011). The transformed nano-goethite samples also plot in a distinct cluster on the magnetic squareness plot (Figure 3c), in contrast to the high remanence ratios and coercivities of the transformed micro-goethite and micro-hematite samples. The extent of secondary magnetite formation 
indicated by saturation magnetization (normalized to the initial concentration of the starting materials) increases slightly with heating time (Table 1) but increases more notably with heating temperature (Figure 3d). The much longer heating times in the capsule heating experiments allow magnetite formation to begin at significantly lower temperatures than observed on short timescales in the thermomagnetic heating curves for the same material. Post-heating $J_{S}$ values indicate that at least $10 \%$ of the initial goethite and hematite in the samples becomes transformed to magnetite after heating at $325^{\circ} \mathrm{C}$ for $64 \mathrm{~h}$. Micro-goethite transforms to the greatest extent at 325 and $350{ }^{\circ} \mathrm{C}$, with estimated conversion rates to magnetite of $32-37 \%$ and $39-47 \%$, respectively.

\subsubsection{FORC distributions}

FORC diagrams for unheated micro-hematite (Figure 4a) and micro-goethite (Figure 5a) each exhibit a central ridge with low interaction fields $\left(H_{U}\right)$. FORC measurements on nanogoethite could not be obtained with an adequate signal-to-noise ratio because the roomtemperature remanence of nano-goethite is practically zero due to its low blocking temperature (Till et al. 2015). The micro-hematite coercivity distribution extends to fields above 150 $\mathrm{mT}$, while that of micro-goethite is restricted to fields below $60 \mathrm{mT}$. Roberts et al. (2006) reported a FORC diagram for Al-free SD hematite similar to that shown here, but they noted that Al-free goethite did not yield suitable FORC data because a $1 \mathrm{~T}$ field was not sufficient to produce a measurable remanence in the sample. We consider non-saturation to be responsible for the apparently low remanence and coercivity of the micro-goethite in this study, however there is also a considerable vertical spread at moderate coercivities in addition to the central ridge-like feature. The source of the larger interaction fields in the background may be some unidentified impurity, however it is also likely to be slightly exaggerated by the higher smoothing factors used in processing the data for this sample. In addition, variations in water content have also been shown to influence the magnetic properties of goethite (Barrero et al. 2006).

The coerciviy ranges of thermo-reduced micro-hematite in FORC diagrams are smaller 
and shifted to lower values and have larger interaction fields (Figure 4b) compared to the starting hematite, reflecting increased concentrations of fine magnetite. Thermo-reduced micro-goethite samples have higher overall coercivities than the starting micro-goethite and a localized peak with limited vertical spread indicating moderate magnetostatic interaction fields (Figure 5b). These magnetite-bearing samples display a teardrop-shaped FORC pattern with a high-coercivity tail that often characterizes interacting SD magnetite, as seen in experimentally disaggregated magnetosome particles (Chen et al. 2007; Li et al. 2012) and some marine sediments (Roberts et al. 2012).

FORC distributions for thermo-reduced nano-goethite (Figure 6) have peaks near the intersection of the $H_{U}$ and $H_{C}$ axes, with a moderate spread of interaction fields near the vertical axis and a broad central ridge that extends parallel to and slightly above the horizontal axis. These features are interpreted to indicate a grain size distribution consisting of a mixture of superparamagnetic and weakly interacting small SD magnetite grains as previously found for magnetite produced from altered nano-goethite by Till et al. (2017). Although FORC distributions for non-interacting SP magnetite typically exhibit a very limited vertical spread (Kumari et al. 2015), Pike et al. (2001) outlined several features of FORCs associated with thermal relaxation effects in fine magnetic particles, including a peak centered on the origin, a minor upward offset in the distribution, and sub-vertical contour lines near the $H_{U}$ axis. All of these features can be observed in the measurements for altered nano-goethite, although the sub-vertical contours in the examples shown by Pike et al. (2001) are more pronounced in the lower left-hand part of the diagram while those in Figure 6 are more symmetrical. Whether the thermal relaxation effects in our samples originate from the hematite or the magnetite or both is unclear. Kumari et al. (2014) also investigated FORC distributions for mixtures of SP and SD magnetite particles and reported similar upward shifts of the distribution as well as a peak at the origin. The diagrams in Figure 6 are similar to their findings for interacting, SP-bearing synthetic magnetite. The difference between our measured FORCs and those of these other studies is attributed to a 
combination of different degrees of interaction, grain size distributions and the mixture of nano-hematite and nano-magnetite phases in the thermo-reduced nano-goethite.

\subsubsection{Alteration product morphologies}

The secondary phases in partially transformed micro-goethite retain the overall size and shape of the original goethite particles, with varying degrees of partial recrystallization depending on the heating temperature. Micro-goethite dehydrated at moderate temperatures $\left(280^{\circ} \mathrm{C}\right.$, Figure $\left.7 \mathrm{a}\right)$ consists of an oriented network of slightly elongated nanoscale hematite crystallites on the order of $10 \mathrm{~nm}$ in size separated by numerous nanopores that accommodate the loss of volume during dehydroxylation. Similar pseudomorphic structures in nano-hematite have been reported by various earlier studies (Naono et al. 1987; Gualtieri \& Venturelli 1999). Particle morphologies in partially transformed micro-hematite samples from capsule heating experiments (not shown) were indistinguishable from those of the starting material.

TEM observations of micro-goethite after thermomagnetic measurements in air (Figure $7 \mathrm{~d}$ ) reveal that grain coarsening and annealing occurs at higher temperatures, resulting in larger hematite particles with a uniform orientation. Thermo-reduced micro-goethite samples that have been largely transformed to magnetite exhibit similar but less distinct porous microstructures (Figure 7b,e). It is unclear from the TEM images whether the thermoreduced goethite particles from capsule heating experiments consist solely of magnetite or a mixture of magnetite and hematite crystallites, as the two phases are difficult to distinguish in TEM. Furthermore, the abundance of pores and other defects makes it difficult to determine the average size of the magnetite or hematite crystallites. Simulated diffraction patterns were created using fast Fourier transforms of high-resolution TEM images, which indicates that both the micro-goethite altered in air and thermo-reduced micro-goethite have a uniform crystallographic orientation of the secondary phases across each particle.

The secondary Fe-oxides produced from nano-goethite consist of equant particles ranging in size from about 5 to $20 \mathrm{~nm}$ (Figure 7c,f). The shapes of the reaction product grains gen- 
erally resemble the initial morphology of the aggregated nano-goethite particles, although the smallest oxide particles are more similar in size to individual nano-goethite crystallites. Unlike in the experiments of Till et al. (2015), who reported complete rapid recrystallization of intermediate defect-rich nano-hematite to highly crystalline SD magnetite, here the secondary magnetite appears to be influenced by the initial nano-goethite grain structure to produce only small SD and SP-size grains.

\subsection{TCRM acquisition}

The results of stepwise TCRM acquisition for mixtures of calcite and goethite or hematite with or without organic $\mathrm{C}$ are shown in Figure 8 as a function of heating temperature. After heating in an applied field at $300^{\circ} \mathrm{C}$ for $60 \mathrm{~min}$, only the nano-goethite $+\mathrm{C}$ sample had a higher remanence than the oxide-free control sample containing only calcite and sugar. Following heating steps above $300^{\circ} \mathrm{C}$, progressive increases in remanence intensity were observed in all samples containing organic C, with a particularly large increase between 500 and $550^{\circ} \mathrm{C}$. This is presumably because the higher heating temperatures approached the blocking-temperature range of the fine-grained secondary magnetite. TCRM acquisition in micro-hematite with organic $\mathrm{C}$ was lower than that of micro-goethite with organic $\mathrm{C}$ by about a factor of 5 , reflecting a lower extent of transformation to magnetite. Thermo-reduced nanogoethite TCRMs were comparable to those of micro-goethite at intermediate temperatures $\left(300-450^{\circ} \mathrm{C}\right)$, but were an order of magnitude lower above $500^{\circ} \mathrm{C}$ after accounting for the different mineral concentrations in each sample. The weak remanence of the transformed nano-goethite is attributed to the high concentration of SP-sized secondary magnetite that does not carry a stable room-temperature remanence. Notably, TCRM acquisition in previously heated and dehydroxylated micro-goethite with organic $\mathrm{C}$ was essentially identical to that of micro-goethite with organic $\mathrm{C}$, as expected for a two-step process involving transformation to hematite followed by reduction to magnetite. Based on the similar behaviors of these two samples, we infer that dehydroxylation occurs rapidly during heating, and that 
organic matter breakdown and reductive recrystallization of poorly crystalline intermediate hematite are the rate-limiting processes for magnetite formation.

AF demagnetization of TCRM was performed after 350, 450, and $600^{\circ} \mathrm{C}$. Each of these measurement series revealed a single component of remanence in orthogonal vector diagrams for each sample (Figure 9). Median destructive fields (MDF) of the TCRMs increase with heating temperatures in all samples except micro-hematite (Figure 10). The higher MDF for micro-hematite with organic $\mathrm{C}$ after heating to $350^{\circ} \mathrm{C}$ reflects the large proportion of unaltered SD hematite suggested by the remanence remaining after AF demagnetization at 100 mT. Micro-hematite without organic C, sample GC06C, acquired a weak but measurable magnetization compared with the C-bearing hematite sample, GC06D. The partial TRM acquired by micro-hematite increases approximately linearly with heating temperature (Figure 8a). TCRM acquired by the micro-goethite control sample, GC06B, was only slightly higher than that of the oxide-free control with a small peak in remanence at $300^{\circ} \mathrm{C}$ and a decrease thereafter (inset, Figure 8b). Following TCRM acquisition at $600^{\circ} \mathrm{C}$, all samples containing organic $\mathrm{C}$ contained a significant amount of remanence compared to the control samples after AF demagnetization at $100 \mathrm{mT}$. The residual remanence in the micro- and nano-goethite samples was approximately 3 orders of magnitude greater than the oxide-free control GC06A $\left(5.1 \times 10^{-1}, 1.9 \times 10^{-1}\right.$ and $4.1 \times 10^{-4} \mathrm{mAm}^{2} / \mathrm{kg}$, respectively, Table S2).

The amount of magnetite formed after each TCRM heating step was not quantified but can be estimated based on the heating durations, which are intermediate between those of the thermomagnetic measurements and the capsule heating experiments. Because the susceptibility vs. $\mathrm{T}$ curves are largely reversible for micro-goethite above $500^{\circ} \mathrm{C}$ and for micro-hematite above $530^{\circ} \mathrm{C}$ (Figure 2d,e), the majority of magnetite formation in microhematite and micro-goethite samples during the TCRM tests is estimated to occur between 300 and $500^{\circ} \mathrm{C}$, while nano-goethite begins to produce magnetite slightly below $300^{\circ} \mathrm{C}$. The increases in magnetization intensity between 300 and $500^{\circ} \mathrm{C}$ are therefore interpreted to represent both increasing magnetite formation as well as partial thermal remanence acquisition at elevated temperatures, while the larger increases in remanence intensity above $500^{\circ} \mathrm{C}$ 
primarily reflect more complete thermal magnetization of fine-grained magnetite, most of which has blocking temperatures close to $580^{\circ} \mathrm{C}$.

\section{DISCUSSION}

\subsection{Goethite transformation process}

A number of studies have demonstrated that the phase obtained from goethite dehydroxylation at moderate temperatures $\left(200-350^{\circ} \mathrm{C}\right)$ is not stoichiometric hematite, but rather an Fe-deficient hematite with excess $\mathrm{OH}^{-}$groups termed "protohematite" (Wolska \& Schwertmann 1989; Gualtieri \& Venturelli 1999; Gialanella et al. 2010). The residual hydroxyl groups are only removed and pure stoichiometric hematite formed after heating to higher temperatures of around $800^{\circ} \mathrm{C}$. Thus, the intermediate phase that becomes reduced to form magnetite after goethite dehydroxylation is likely "protohematite" or a related phase rather than pure hematite. Landers \& Gilkes (2007) found that defect-rich non-stoichiometric hematite derived from dehydroxylation of Ni-bearing goethite exhibited enhanced dissolution kinetics relative to more crystalline hematite. Based on these findings, "protohematite" may reasonably be expected to be less stable and more reactive than stoichiometric hematite with respect to reductive transformation to magnetite. The synthetic hematite investigated in this study does display a slightly lower extent of transformation than the goethite samples in capsule heating experiments performed at 325 and $350^{\circ} \mathrm{C}$ (Figure $3 \mathrm{~d}$ ) and begins to transform to magnetite at slighter higher temperatures in thermomagnetic measurements. While the presence of crystal defects and non-stoichiometry in "protohematite" does not appear to have a significant effect for the timescales studied in these experiments, these features could potentially enhance goethite transformation rates over geological timescales.

The morphology of secondary magnetite obtained from goethite is difficult to determine in the present experiments. The reductive transformation process consists of two sequential topotactic transformations from goethite to hematite, and hematite to magnetite. These sequential processes generate nanoscale oriented aggregates of hematite and magnetite that pseudomorph the original goethite morphology, although in more strongly reducing con- 
ditions nano-goethite can recrystallize completely so that the original particle appearance is obscured (Till et al. 2017). Saturation magnetization values for all capsule heating experiments are much lower than those expected for complete transformation to magnetite, indicating that these samples contain either a mixture of hematite and magnetite or (more likely) intergrowths of the two phases. Furthermore, the FORC distributions demonstrate that significant magnetostatic interactions are present in all thermo-reduced samples, even those that are weakly reacted and contain small $(\approx 1 \%)$ initial concentrations of goethite. From this observation we infer that the $H_{U}$ fields in FORC diagrams for thermo-reduced goethite arise from intra-particle interactions produced by neighboring crystallites of secondary magnetite within a matrix of secondary hematite rather than inter-particle interactions. The SD-like hysteresis parameters of magnetite formed in micro-goethite suggests that these crystallites are larger than those formed from nano-goethite, however further high-resolution microscopy investigations are needed to fully characterize the textures of these sub-microscopic mineral intergrowths.

Various recent studies have begun to clarify the complex interactions between oriented particle growth and phase transformations in iron oxides, particularly the formation of crystalline oxides such as magnetite and hematite from poorly crystalline Fe-(oxyhydr)oxide phases (Frandsen et al. 2014; Reichel et al. 2017). The mechanisms of secondary phase growth during transformation strongly control the nanostructure of the product oxide phase, and therefore its magnetic properties (Reufer et al. 2010, 2011). Further detailed study of the oriented structures in nanocrystalline goethite and proto-hematite is warranted to better understand their prevalence in the environment as well as their reactivity and evolution over time.

\subsection{Implications for goethite transformation in soils}

The high-purity synthetic goethite and hematite used in this study vary in a few respects from those found in natural soils. Pedogenic goethite and hematite often occur with a range of impurities, both substitutional and adsorbed to the surface, such as Al. Earlier studies 
have shown that Al-substituted goethite undergoes dehydroxylation at higher temperatures, effectively stabilizing goethite against transformation (Ruan \& Gilkes 1995). This aspect may explain the findings of some researchers that temperatures of over $400^{\circ} \mathrm{C}$ during wildfires are needed to produce fine magnetic particles in soil (Rummery 1983; Oldfield \& Crowther 2007). On the other hand, hematite, goethite and other oxyhydroxides in soils and sediments have a strong tendency to bind or adsorb organic matter (Tipping \& Cooke 1982; Caner et al. 2011), which could destabilize the minerals and facilitate their transformation during heating by wildfire. Additionally, interaction processes between Fe-oxides and clay minerals that contain either structural or adsorbed Fe Hirt et al. (1993); Zhang et al. (2012) need to be studied in greater detail.

The reaction kinetics of the goethite dehydroxylation to hematite transformation have been characterized in detail by Ruan \& Gilkes (1996) and goethite is reported to be stable against dehydroxylation to hematite up to $100^{\circ} \mathrm{C}$ (Koch et al. 1986). Although Langmuir (1971) predicted that nano-goethite should be metastable relative to hematite on geological timescales, no evidence has been found to suggest that this transformation occurs at ambient surface conditions. Laboratory bioreduction experiments with goethite and hematite typically report a limited extent of Fe reduction by dissimilatory metal-reducing bacteria (Cooper et al. 2000; Hansel et al. 2004). This is likely a result of the low solubility of these crystalline oxides compared with easily reducible ferric phases such as ferrihydrite and lepidocrocite because mineral bioreduction rates have been shown to correlate with reductive dissolution rates (Bonneville et al. 2004). Adsorption of $\mathrm{Fe}(\mathrm{II})$ on goethite surfaces also tends to lowers the mineral reactivity over time (Roden 2004). Furthermore, microbially mediated transformation of goethite to magnetite has not been achieved experimentally, while bacterial transformation of hematite to magnetite only takes place under specific chemical conditions (Behrends \& Van Cappellen 2007).

Wetting-drying cycles that produce alternately oxic and anoxic conditions have been proposed to play a role in Fe mineral transformations in soils. Redox cycling experiments on a nano-goethite-bearing soil by Thompson et al. (2006) found that goethite crystallinity 
increased over time, suggesting that periodic anoxic conditions actually decrease goethite reactivity as nano-goethite is converted to micro-goethite. Solid-state transformations of goethite are thus unlikely to occur at ambient temperatures in soils and shallow sediments. Rather, dissolution-precipitation processes such as proton- or ligand-promoted dissolution (Holmén \& Casey 1996; Wiederhold et al. 2006) are more likely to be the primary agents of goethite and hematite transformation in unheated soils. Similarly, dissolved Fe(II) in the presence of certain organic ligands, such as oxalate, has been shown to catalyze the dissolution of goethite (Poulton \& Canfield 2005).

\subsection{TCRM acquisition during goethite transformation}

As noted by Özdemir \& Dunlop (2000), the formation of magnetite from goethite could have significant effects on the magnetization of goethite-bearing rocks or sediments. The altered goethite samples investigated in this study are composed of either secondary hematite (without organic C) or a mixture of secondary hematite and magnetite (with organic C). While the TCRMs acquired by the organic C-bearing goethite samples are largely demagnetized by $100 \mathrm{mT}$, a significant amount of remanence remains after demagnetization, the source of which is unclear. It may be held by SD magnetite with coercivites above $100 \mathrm{mT}$, or it could be a result of magnetite that has begun to oxidize back to hematite or maghemite at high temperatures. However, the very weak TCRM acquired by the goethite control sample (without organic C), which was similar in magnitude to the oxide-free control sample, suggests that the secondary hematite that forms directly from the goethite is unlikely to carry the residual remanence in the altered C-bearing samples.

The hematite crystallite size of 3-8 nm determined by Till et al. (2015) in dehydrated nano-goethite is well below the room-temperature SD size threshold of $27 \mathrm{~nm}$ for Al-free hematite given by Jiang et al. (2014). The TEM observations of partially altered microgoethite in Figure 7a indicate a hematite crystallite size of around 10-15 nm. Although the secondary pseudomorphic hematite should have a dominantly SP domain state, the close spacing of the crystallites within the particle aggregates may give rise to magnetostatic in- 
teractions that produce more SD-like behavior. This may explain the low room-temperature coercivity observed in the dehydrated micro-goethite shown in red in Figure 3a as well as the weak TCRM in sample GC06B (Figure 8b) and its relatively low MDF values (Figure 10). However, this does not preclude the possibility that reducing conditions facilitated recrystallization and and grain growth of secondary nano-hematite from SP-sized crystallites to larger SD hematite grains. Because poorly crystalline phases tend to undergo grain growth and annealing at elevated temperatures over extended periods of time, the nanophase hematite morphology observed in these experiments may be difficult to preserve in ancient rocks.

Remagnetization is a common feature of sedimentary rocks in many localities (Van Der Voo \& Torsvik 2012) that has been particularly well documented for Paleozoic rocks of North America (McCabe \& Elmore 1989). The secondary magnetizations are nearly always chemical in origin and often associated with the formation of fine-grained authigenic magnetite or hematite or both (Zwing et al. 2005). A number of possible remagnetization mechanisms have been proposed, including pyrite oxidation catalyzed by $\mathrm{Fe}^{3+}$-organic complexes (Brothers et al. 1996) and various fluid alteration processes, which Elmore et al. (2012) broadly groups into alteration by external fluids and fluid-assisted burial diagenesis. Some evidence also suggestions that hydrocarbon migration may be linked to remagnetization in some settings (Machel 1995; Cioppa \& Symons 2000; Mena \& Walther 2012). Although in many cases the specific chemical processes that produce secondary magnetite are unclear, some studies suggest the involvement of reducing conditions (Donovan et al. 1979) or liberation of $\mathrm{Fe}^{2+}$, for example during clay mineral transformation from smectite to illite (Gill et al. 2002). The results of this study demonstrate that goethite can also provide a readily available iron source or act as a substrate for iron reduction that leads to formation of fine-grained magnetite during alteration of sedimentary rocks. Alteration of nano-goethite in particular generates a mixture of SP and small SD magnetite grains similar to those that have been described in various remagnetized carbonate rocks (Riquier et al. 2010; Da Silva et al. 2012). The stable TCRMs produced in our experiments further demonstrate that 
goethite alteration represents a feasible alternative pathway for chemical remagnetization due to authigenic magnetite formation.

\section{CONCLUSIONS}

The results of experimental thermal transformations of microcrystalline goethite and hematite indicate that both phases partially alter in the presence of an organic carbon reductant to produce dominantly single-domain magnetite. Micro-goethite transforms to magnetite to a greater extent than micro-hematite because of high defect concentrations and surface area in the poorly crystalline intermediate hematite formed following dehydroxylation, which promote greater reactivity. Nanocrystalline goethite heated in the presence of organic carbon partially alters to form magnetite particles with characteristics of small single-domain and superparamagnetic grains, in contrast to the dominantly stable SD magnetite produced by nano-goethite heated in a gas atmosphere (Till et al. 2015). Secondary magnetite and/or hematite formed during heating in an applied field acquire a single component of stable thermo-chemical remanence, whose strength increases as the heating temperature approaches the blocking temperature range of the secondary phases. Goethite is therefore an feasible substrate for authigenic magnetite formation and the generation of secondary chemical remanence in altered sedimentary rocks.

\section{ACKNOWLEDGMENTS}

The authors thanks Richard Wirth for assistance with TEM imaging. The manuscript benefited from constructive reviews by Ann Hirt and Doug Elmore and editorial comments from Eduard Petrovsky. The author's research stay in Germany was supported by a fellowship from the Alexander von Humboldt Foundation.

\section{REFERENCES}

Abrajevitch, A., Van der Voo, R., \& Rea, D. K., 2009. Variations in relative abundances of goethite and hematite in Bengal Fan sediments: Climatic vs. diagenetic signals, Marine Geology, 267(3), 
$191-206$.

Anand, R. \& Gilkes, R., 1987. The association of maghemite and corundum in Darling Range laterites, Western Australia, Soil Research, 25(3), 303-311.

Barrero, C., Betancur, J., Greneche, J., Goya, G., \& Berquó, T., 2006. Magnetism in nonstoichiometric goethite of varying total water content and surface area, Geophysical Journal International, 164(2), 331-339.

Behrends, T. \& Van Cappellen, P., 2007. Transformation of hematite into magnetite during dissimilatory iron reductionconditions and mechanisms, Geomicrobiology Journal, 24(5), 403416.

Bonneville, S., Van Cappellen, P., \& Behrends, T., 2004. Microbial reduction of iron (iii) oxyhydroxides: effects of mineral solubility and availability, Chemical Geology, 212(3-4), 255-268.

Brothers, L., Engel, M., \& Elmore, R., 1996. The late diagenetic conversion of pyrite to magnetite by organically complexed ferric iron, Chemical Geology, 130(1-2), 1-14.

Caner, L., Petit, S., Joussein, E., Fritsch, E., \& Herbillon, A., 2011. Accumulation of organometallic complexes in laterites and the formation of Aluandic Andosols in the Nilgiri Hills (southern India): Similarities and differences with Umbric Podzols, European Journal of Soil Science, 62(5), 754-764.

Chen, A. P., Egli, R., \& Moskowitz, B. M., 2007. First-order reversal curve (FORC) diagrams of natural and cultured biogenic magnetic particles, Journal of Geophysical Research: Solid Earth (1978-2012), 112(B8), B08S90.

Cioppa, M. \& Symons, D., 2000. Timing of hydrocarbon generation and migration: paleomagnetic and rock magnetic analysis of the devonian duvernay formation, alberta, canada, Journal of Geochemical Exploration, 69, 387-390.

Clement, B. M., Javier, J., Sah, J. P., \& Ross, M. S., 2011. The effects of wildfires on the magnetic properties of soils in the Everglades, Earth Surface Processes and Landforms, 36(4), 460-466.

Cooper, D. C., Picardal, F., Rivera, J., \& Talbot, C., 2000. Zinc immobilization and magnetite formation via ferric oxide reduction by shewanella putrefaciens 200, Environmental science 8 technology, 34(1), 100-106.

Cudennec, Y. \& Lecerf, A., 2005. Topotactic transformations of goethite and lepidocrocite into hematite and maghemite, Solid State Sciences, 7(5), 520-529.

Da Silva, A.-C., Dekkers, M. J., Mabille, C., \& Boulvain, F., 2012. Magnetic susceptibility and its relationship with paleoenvironments, diagenesis and remagnetization: examples from the Devonian carbonates of Belgium, Studia Geophysica et Geodaetica, 56(3), 677-704.

De Boer, C. B. \& Dekkers, M. J., 2001. Unusual thermomagnetic behaviour of haematites: neoformation of a highly magnetic spinel phase on heating in air, Geophysical Journal International, 
144(2), 481-494.

Dekkers, M., 1990. Magnetic properties of natural goethiteIII. Magnetic behaviour and properties of minerals originating from goethite dehydration during thermal demagnetization, Geophysical Journal International, 103(1), 233-250.

Deng, C., Zhu, R., Verosub, K. L., Singer, M. J., \& Vidic, N. J., 2004. Mineral magnetic properties of loess/paleosol couplets of the central loess plateau of china over the last $1.2 \mathrm{myr}$, Journal of Geophysical Research: Solid Earth, 109(B1).

Donovan, T. J., Forgey, R. L., \& Roberts, A. A., 1979. Aeromagnetic detection of diagenetic magnetite over oil fields: Geologic notes, AAPG Bulletin, 63(2), 245-248.

Dunlop, D. J., 2014. High-temperature susceptibility of magnetite: a new pseudo-single-domain effect, Geophysical Journal International, 199(2), 707-716.

Elmore, R. D., Muxworthy, A. R., \& Aldana, M., 2012. Remagnetization and chemical alteration of sedimentary rocks, Geological Society, London, Special Publications, 371(1), 1-21.

Fabian, K., Shcherbakov, V., \& McEnroe, S., 2013. Measuring the Curie temperature, Geochemistry, Geophysics, Geosystems, 14(4), 947-961.

Francombe, M. \& Rooksby, H., 1959. Structure transformation effects by the dehydration of diaspore, goethite and delta ferric oxide, Clay Minerals Bulletin, 4(21), 1-14.

Frandsen, C., Legg, B. A., Comolli, L. R., Zhang, H., Gilbert, B., Johnson, E., \& Banfield, J. F., 2014. Aggregation-induced growth and transformation of $\beta$-feooh nanorods to micron-sized $\alpha$-fe 2 o 3 spindles, CrystEngComm, 16(8), 1451-1458.

Frank, U. \& Nowaczyk, N. R., 2008. Mineral magnetic properties of artificial samples systematically mixed from haematite and magnetite, Geophysical Journal International, 175(2), 449-461.

Gialanella, S., Girardi, F., Ischia, G., Lonardelli, I., Mattarelli, M., \& Montagna, M., 2010. On the goethite to hematite phase transformation, Journal of Thermal Analysis and Calorimetry, 102(3), 867-873.

Gill, J. D., Elmore, R., \& Engel, M., 2002. Chemical remagnetization and clay diagenesis: testing the hypothesis in the cretaceous sedimentary rocks of northwestern montana, Physics and Chemistry of the Earth, Parts A/B/C, 27(25-31), 1131-1139.

Goldsztaub, S., 1931. Deshydratation des hydrates ferriques naturel, Comptes rendus de lAcadémie des Sciences, 193, 533-535.

Goss, C., 1987. The kinetics and reaction mechanism of the goethite to hematite transformation, Mineralogical Magazine, 51(361), 437-451.

Grogan, K. L., Gilkes, R. J., \& Lottermoser, B. G., 2003. Maghemite formation in burnt plant litter at East Trinity, North Queensland, Australia, Clays and Clay Minerals, 51(4), 390-396.

Gualtieri, A. F. \& Venturelli, P., 1999. In situ study of the goethite-hematite phase transformation 
by real time synchrotron powder diffraction, American Mineralogist, 84(5-6), 895-904.

Guyodo, Y., Mostrom, A., Lee Penn, R., \& Banerjee, S. K., 2003. From nanodots to nanorods: Oriented aggregation and magnetic evolution of nanocrystalline goethite, Geophysical Research Letters, 30(10), 1512.

Hanesch, M., Stanjek, H., \& Petersen, N., 2006. Thermomagnetic measurements of soil iron minerals: The role of organic carbon, Geophysical Journal International, 165(1), 53-61.

Hansel, C. M., Benner, S. G., Nico, P., \& Fendorf, S., 2004. Structural constraints of ferric (hydr)oxides on dissimilatory iron reduction and the fate of Fe (II), Geochimica et Cosmochimica Acta, 68(15), 3217-3229.

Harrison, R. J. \& Feinberg, J. M., 2008. FORCinel: An improved algorithm for calculating firstorder reversal curve distributions using locally weighted regression smoothing, Geochemistry, Geophysics, Geosystems, 9(5), 2008Q05016.

Heller, F., 1978. Rock magnetic studies of upper jurassic limestones from southern germany, $J$. geophys, 44, 525-543.

Hirt, A., Banin, A., \& Gehring, A., 1993. Thermal generation of ferromagnetic minerals from iron-enriched smectites, Geophysical Journal International, 115(3), 1161-1168.

Holmén, B. A. \& Casey, W. H., 1996. Hydroxamate ligands, surface chemistry, and the mechanism of ligand-promoted dissolution of goethite $[\alpha-\mathrm{FeOOH}(\mathrm{s})]$, Geochimica et Cosmochimica Acta, 60(22), 4403-4416.

Hunt, C. P., Moskowitz, B. M., \& Banerjee, S. K., 1995. Magnetic properties of rocks and minerals, in Rock Physics $\mathcal{E}$ Phase Relations: A Handbook of Physical Constants, pp. 189-204, American Geophysical Union.

Ibrahim, M., Edwards, G., Seehra, M., Ganguly, B., \& Huffman, G., 1994. Magnetism and spin dynamics of nanoscale FeOOH particles, Journal of Applied Physics, 75(10), 5873-5875.

Jiang, Z., Liu, Q., Dekkers, M. J., Colombo, C., Yu, Y., Barrón, V., \& Torrent, J., 2014. Ferro and antiferromagnetism of ultrafine-grained hematite, Geochemistry, Geophysics, Geosystems, 15(6), 2699-2712.

Ketterings, Q. M., Bigham, J. M., \& Laperche, V., 2000. Changes in soil mineralogy and texture caused by slash-and-burn fires in Sumatra, Indonesia, Soil Science Society of America Journal, 64(3), 1108-1117.

Koch, C. J., Madsen, M., Mørup, S., Christiansen, G., Gerward, L., \& Villadsen, J., 1986. Effect of heating on microcrystalline synthetic goethite, Clays and Clay Minerals, 34(1), 17-24.

Kumari, M., Widdrat, M., Tompa, É., Uebe, R., Schüler, D., Pósfai, M., Faivre, D., \& Hirt, A. M., 2014. Distinguishing magnetic particle size of iron oxide nanoparticles with first-order reversal curves, Journal of Applied Physics, 116(12), 124304. 
Kumari, M., Hirt, A. M., Uebe, R., Schüler, D., Tompa, E., Pósfai, M., Lorenz, W., Ahrentorp, F., Jonasson, C., \& Johansson, C., 2015. Experimental mixtures of superparamagnetic and singledomain magnetite with respect to day-dunlop plots, Geochemistry, Geophysics, Geosystems, 16(6), 1739-1752.

Landers, M. \& Gilkes, R. J., 2007. Dehydroxylation and dissolution of nickeliferous goethite in New Caledonian lateritic Ni ore, Applied Clay Science, 35(3), 162-172.

Langmuir, D., 1971. Particle size effect on the reaction goethite $=$ hematite + water, American Journal of Science, 271(2), 147-156.

Li, J., Wu, W., Liu, Q., \& Pan, Y., 2012. Magnetic anisotropy, magnetostatic interactions and identification of magnetofossils, Geochemistry, Geophysics, Geosystems, 13(12), 2012Q10Z51.

Lima-de Faria, J., 1963. Dehydration of goethite and diaspore, Zeitschrift für KristallographieCrystalline Materials, 119(1-6), 176-203.

Lima-de Faria, J., 1967. Anomalous orientations of cubic close packing in the dehydration of goethite in an inert atmosphere, Acta Crystallographica, 23(5), 733-736.

Lowrie, W. \& Heller, F., 1982. Magnetic properties of marine limestones, Reviews of Geophysics, $\mathbf{2 0}(2), 171-192$.

Machel, H. G., 1995. Magnetic mineral assemblages and magnetic contrasts in diagenetic environmentswith implications for studies of palaeomagnetism, hydrocarbon migration and exploration, Geological Society, London, Special Publications, 98(1), 9-29.

McCabe, C. \& Elmore, R. D., 1989. The occurrence and origin of late Paleozoic remagnetization in the sedimentary rocks of North America, Reviews of Geophysics, 27(4), 471-494.

Mena, M. \& Walther, A., 2012. Rock magnetic properties of drill cutting from a hydrocarbon exploratory well and their relationship to hydrocarbon presence and petrophysical properties, Geological Society, London, Special Publications, 371(1), 217-228.

Naono, H., Nakai, K., Sueyoshi, T., \& Yagi, H., 1987. Porous texture in hematite derived from goethite: Mechanism of thermal decomposition of goethite, Journal of Colloid and Interface Science, 120(2), 439-450.

Nørnberg, P., Vendelboe, A. L., Gunnlaugsson, H. P., Merrison, J. P., Finster, K., \& Jensen, S. K., 2009. Comparison of the mineralogical effects of an experimental forest fire on a goethite/ferrihydrite soil with a topsoil that contains hematite, maghemite and goethite, Clay Minerals, 44(2), 239-247.

Oldfield, F. \& Crowther, J., 2007. Establishing fire incidence in temperate soils using magnetic measurements, Palaeogeography, Palaeoclimatology, Palaeoecology, 249(3), 362-369.

Özdemir, Ö. \& Banerjee, S. K., 1984. High temperature stability of maghemite $\left(\gamma-\mathrm{Fe}_{2} \mathrm{O}_{3}\right)$, Geophysical Research Letters, 11(3), 161-164. 
Özdemir, Ö. \& Dunlop, D. J., 2000. Intermediate magnetite formation during dehydration of goethite, Earth and Planetary Science Letters, 177(1), 59-67.

Pfeiffer, H. \& Schüppel, W., 1994. Temperature dependence of the magnetization in fine particle systems and the Hopkinson effect. Application to barium ferrite powders, Journal of magnetism and magnetic materials, 130(1-3), 92-98.

Pike, C. R., Roberts, A. P., \& Verosub, K. L., 2001. First order reversal curve diagrams and thermal relaxation effects in magnetic particles, Geophysical Journal International, 145(3), 721730.

Poulton, S. W. \& Canfield, D. E., 2005. Development of a sequential extraction procedure for iron: implications for iron partitioning in continentally derived particulates, Chemical Geology, 214(3), 209-221.

Reichel, V., Kovács, A., Kumari, M., Bereczk-Tompa, É., Schneck, E., Diehle, P., Pósfai, M., Hirt, A. M., Duchamp, M., Dunin-Borkowski, R. E., et al., 2017. Single crystalline superstructured stable single domain magnetite nanoparticles, Scientific Reports, 7, 45484.

Reufer, M., Dietsch, H., Gasser, U., Hirt, A., Menzel, A., \& Schurtenberger, P., 2010. Morphology and orientational behavior of silica-coated spindle-type hematite particles in a magnetic field probed by small-angle x-ray scattering, The Journal of Physical Chemistry B, 114(14), 47634769.

Reufer, M., Dietsch, H., Gasser, U., Grobety, B., Hirt, A., Malik, V. K., \& Schurtenberger, P., 2011. Magnetic properties of silica coated spindle-type hematite particles, Journal of Physics: Condensed Matter, 23(6), 065102.

Riquier, L., Averbuch, O., Devleeschouwer, X., \& Tribovillard, N., 2010. Diagenetic versus detrital origin of the magnetic susceptibility variations in some carbonate Frasnian-Famennian boundary sections from Northern Africa and Western Europe: implications for paleoenvironmental reconstructions, International Journal of Earth Sciences, 99(1), 57-73.

Roberts, A. P., Liu, Q., Rowan, C. J., Chang, L., Carvallo, C., Torrent, J., \& Horng, C.-S., 2006. Characterization of hematite $\left(\alpha-\mathrm{Fe}_{2} \mathrm{O}_{3}\right)$, goethite $(\alpha-\mathrm{FeOOH})$, greigite $\left(\mathrm{Fe}_{3} \mathrm{~S}_{4}\right)$, and pyrrhotite $\left(\mathrm{Fe}_{7} \mathrm{~S}_{8}\right)$ using first-order reversal curve diagrams, Journal of Geophysical Research: Solid Earth, 111(B12), B12S35.

Roberts, A. P., Chang, L., Heslop, D., Florindo, F., \& Larrasoaña, J. C., 2012. Searching for single domain magnetite in the pseudo-single-domain sedimentary haystack: Implications of biogenic magnetite preservation for sediment magnetism and relative paleointensity determinations, Journal of Geophysical Research: Solid Earth (1978-2012), 117(B8), B08104.

Roden, E. E., 2004. Analysis of long-term bacterial vs. chemical fe (iii) oxide reduction kinetics1, Geochimica et Cosmochimica Acta, 68(15), 3205-3216. 
Rooksby, H., 1951. Effect of heat-treatment on goethite and lepidocrocite, X-ray identification and crystal structures of clay minerals, pp. 260-261.

Ruan, H. \& Gilkes, R., 1996. Kinetics of thermal dehydroxylation of aluminous goethite, Journal of Thermal Analysis, 46(5), 1223-1238.

Ruan, H. D. \& Gilkes, R. J., 1995. Dehydroxylation of aluminous goethite: Unit cell dimensions, crystal size and surface area, Clays and Clay Minerals, 43(2), 196-211.

Rude, P. D. \& Aller, R. C., 1989. Early diagenetic alteration of lateritic particle coatings in Amazon continental shelf sediment, Journal of Sedimentary Research, 59(5), 704-716.

Rummery, T., 1983. The use of magnetic measurements in interpreting the fire histories of lake drainage basins, Hydrobiologia, 103(1), 53-58.

Sadeh, B., Doi, M., Shimizu, T., \& Matsui, M., 2000. Dependence of the Curie temperature on the diameter of $\mathrm{Fe}_{3} \mathrm{O}_{4}$ ultra-fine particles, Journal of the Magnetics Society of Japan, 24(4/2), $511-514$

Schwertmann, U. \& Cornell, R. M., 2007. Iron Oxides in the Laboratory, Wiley-VCH Verlag $\mathrm{GmbH}$.

Schwertmann, U. \& Fechter, H., 1984. The influence of aluminum on iron oxides: XI. Aluminumsubstituted maghemite in soils and its formation, Soil Science Society of America Journal, 48(6), $1462-1463$.

Shcherbakov, V., Fabian, K., Sycheva, N., \& McEnroe, S., 2012. Size and shape dependence of the magnetic ordering temperature in nanoscale magnetic particles, Geophysical Journal International, 191(3), 954-964.

Smith, H. G., Blake, W. H., \& Owens, P. N., 2013. Discriminating fine sediment sources and the application of sediment tracers in burned catchments: A review, Hydrological Processes, 27(6), 943-958.

Strangway, D., Honea, R., McMahon, B., \& Larson, E., 1968. The magnetic properties of naturally occurring goethite, Geophysical Journal International, 15(4), 345-359.

Thompson, A., Chadwick, O. A., Rancourt, D. G., \& Chorover, J., 2006. Iron-oxide crystallinity increases during soil redox oscillations, Geochimica et Cosmochimica Acta, 70(7), 1710-1727.

Till, J., Jackson, M., Rosenbaum, J., \& Solheid, P., 2011. Magnetic properties in an ash flow tuff with continuous grain size variation: A natural reference for magnetic particle granulometry, Geochem. Geophys. Geosyst., 12(7), Q07Z26.

Till, J., Guyodo, Y., Lagroix, F., Morin, G., \& Ona-Nguema, G., 2015. Goethite as a potential source of magnetic nanoparticles in sediments, Geology, 43(1), 75-78.

Till, J. L., Guyodo, Y., Lagroix, F., Morin, G., Menguy, N., \& Ona-Nguema, G., 2017. Presumed magnetic biosignatures observed in magnetite derived from abiotic reductive alteration 
of nanogoethite, Comptes Rendus Geoscience, 349(2), 63-70.

Tipping, E. \& Cooke, D., 1982. The effects of adsorbed humic substances on the surface charge of goethite $(\alpha-\mathrm{FeOOH})$ in freshwaters, Geochimica et Cosmochimica Acta, 46(1), 75-80.

Van Der Voo, R. \& Torsvik, T. H., 2012. The history of remagnetization of sedimentary rocks: deceptions, developments and discoveries, Geological Society, London, Special Publications, 371(1), $23-53$.

van der Zee, C., Roberts, D., Rancourt, D., \& Slomp, C., 2003. Nanogoethite is the dominant reactive oxyhydroxide phase in lake and marine sediments, Geology, 31(11), 993-996.

Van Oorschot, I. \& Dekkers, M., 1999. Dissolution behaviour of fine-grained magnetite and maghemite in the citrate-bicarbonate-dithionite extraction method, Earth and Planetary Science Letters, 167(3), 283-295.

Whicker, J. J., Breshears, D. D., Wasiolek, P. T., Kirchner, T. B., Tavani, R. A., Schoep, D. A., \& Rodgers, J. C., 2002. Temporal and spatial variation of episodic wind erosion in unburned and burned semiarid shrubland, Journal of Environmental Quality, 31(2), 599-612.

Wiederhold, J. G., Kraemer, S. M., Teutsch, N., Borer, P. M., Halliday, A. N., \& Kretzschmar, R., 2006. Iron isotope fractionation during proton-promoted, ligand-controlled, and reductive dissolution of goethite, Environmental Science $\&$ Technology, 40(12), 3787-3793.

Wolska, E. \& Schwertmann, U., 1989. Nonstoichiometric structures during dehydroxylation of goethite, Zeitschrift für Kristallographie-Crystalline Materials, 189(1-4), 223-238.

Zhang, C., Paterson, G. A., \& Liu, Q., 2012. A new mechanism for the magnetic enhancement of hematite during heating: the role of clay minerals, Studia Geophysica et Geodaetica, 56(3), $845-860$.

Zwing, A., Matzka, J., Bachtadse, V., \& Soffel, H., 2005. Rock magnetic properties of remagnetized Palaeozoic clastic and carbonate rocks from the NE Rhenish massif, Germany, Geophysical Journal International, 160(2), 477-486. 
Table 1. Experimental conditions and hysteresis parameters for capsule heating experiments with goethite (Gt) and hematite (Hm).

\begin{tabular}{|c|c|c|c|c|c|c|c|c|c|c|}
\hline Experiment & Sample & $\begin{array}{l}\mathrm{T} \\
\left({ }^{\circ} \mathrm{C}\right)\end{array}$ & $\begin{array}{l}\text { time } \\
\text { (hours) }\end{array}$ & material & $\begin{array}{l}\text { organic } \mathrm{C} \text { : } \\
\text { mineral ratio }\end{array}$ & $\begin{array}{l}M_{s} \\
\left(\mathrm{Am}^{2} / \mathrm{kg}\right)\end{array}$ & $\begin{array}{l}M_{r} \\
\left(\mathrm{Am}^{2} / \mathrm{kg}\right)\end{array}$ & $M_{r} / M_{s}$ & $\begin{array}{l}H_{c} \\
(\mathrm{mT})\end{array}$ & $\begin{array}{l}\text { \% conversion } \\
\text { to magnetite }\end{array}$ \\
\hline \multicolumn{2}{|c|}{ Starting material } & - & - & micro-Hm & $\mathrm{N} / \mathrm{A}$ & 0.421 & 0.183 & 0.43 & 26 & $\mathrm{~N} / \mathrm{A}$ \\
\hline \multicolumn{2}{|c|}{ Starting material } & - & - & micro-Gt & $\mathrm{N} / \mathrm{A}$ & $1.22 \times 10^{-2}$ & $1.23 \times 10^{-3}$ & 0.10 & 8.8 & $\mathrm{~N} / \mathrm{A}$ \\
\hline \multicolumn{2}{|c|}{ Starting material } & - & - & nano-Gt & $\mathrm{N} / \mathrm{A}$ & $4.64 \times 10^{-3}$ & $2.43 \times 10^{-4}$ & 0.05 & 4.6 & $\mathrm{~N} / \mathrm{A}$ \\
\hline \multirow[t]{5}{*}{ GA-13 } & A & 250 & 64 & micro-Hm & $1: 3$ & 0.407 & 0.172 & 0.42 & 30 & $<<1$ \\
\hline & $\mathrm{B}$ & 250 & 64 & micro-Gt & $1: 3$ & 0.161 & 0.045 & 0.28 & 39 & $<<1$ \\
\hline & $\mathrm{C}$ & 250 & 64 & $15 \%$ micro-Gt in calcite & $1: 3$ & $5.30 \times 10^{-2}$ & $2.22 \times 10^{-2}$ & 0.42 & 34 & $<1$ \\
\hline & $\mathrm{D}$ & 250 & 64 & $10 \%$ nano-Gt in calcite & $2: 1$ & $6.09 \times 10^{-3}$ & $8.65 \times 10^{-4}$ & 0.14 & 7.4 & $<1$ \\
\hline & $\mathrm{E}$ & 250 & 64 & $5 \%$ micro-Hm in calcite & $2: 1$ & $2.37 \times 10^{-2}$ & $9.93 \times 10^{-3}$ & 0.42 & 30 & $<1$ \\
\hline GA-14 & $\mathrm{A}$ & 280 & 22 & micro-Gt & $1: 3$ & 1.998 & 0.901 & 0.45 & 33 & 2.2 \\
\hline \multirow[t]{7}{*}{ GA-15 } & $\mathrm{A}$ & 350 & 64 & micro-Gt & $1: 3$ & 43.5 & 14.7 & 0.34 & 20 & 47 \\
\hline & $\mathrm{B}$ & 350 & 64 & $5 \%$ micro-Gt in calcite & $2: 1$ & 1.79 & 0.638 & 0.36 & 19 & 39 \\
\hline & $\mathrm{C}$ & 350 & 64 & $1 \%$ micro-Gt in calcite & $2: 1$ & 0.392 & 0.155 & 0.39 & 17 & 43 \\
\hline & $\mathrm{D}$ & 350 & 64 & $5 \%$ micro-Hm in calcite & $2: 1$ & 14.2 & 4.91 & 0.35 & 28 & 15 \\
\hline & $\mathrm{E}$ & 350 & 64 & $1 \%$ micro-Hm in calcite & $2: 1$ & $7.23 \times 10^{-2}$ & $2.62 \times 10^{-2}$ & 0.36 & 19 & 8 \\
\hline & $\mathrm{F}$ & 350 & 64 & $1 \%$ nano-Gt in calcite & $2: 1$ & 0.235 & $1.75 \times 10^{-2}$ & 0.07 & 2.7 & 26 \\
\hline & G & 350 & 64 & $10 \%$ nano-Gt in calcite & $2: 1$ & 1.13 & 0.108 & 0.10 & 4.0 & 12 \\
\hline \multirow[t]{6}{*}{ GA-16 } & $\mathrm{A}$ & 300 & 64 & $5 \%$ micro-Gt in calcite & $2: 1$ & 0.332 & 0.141 & 0.43 & 22 & 7 \\
\hline & $\mathrm{B}$ & 300 & 64 & $1 \%$ micro-Gt in calcite & $2: 1$ & $2.30 \times 10^{-2}$ & $9.37 \times 10^{-3}$ & 0.41 & 24 & 2 \\
\hline & $\mathrm{C}$ & 300 & 64 & $5 \%$ micro-Hm in calcite & $2: 1$ & $3.65 \times 10^{-2}$ & $1.52 \times 10^{-2}$ & 0.42 & 25 & $<1$ \\
\hline & $\mathrm{D}$ & 300 & 64 & $1 \%$ micro-Hm in calcite & $2: 1$ & $1.57 \times 10^{-2}$ & $5.24 \times 10^{-3}$ & 0.33 & 20 & 1.7 \\
\hline & $\mathrm{E}$ & 300 & 64 & micro-Gt (no organic $\mathrm{C}$ ) & NA & $2.48 \times 10^{-2}$ & $8.35 \times 10^{-3}$ & 0.34 & 21 & $\mathrm{n} / \mathrm{a}$ \\
\hline & $\mathrm{F}$ & 300 & 64 & $1 \%$ nano-Gt in calcite & $2: 1$ & 0.124 & $1.88 \times 10^{-2}$ & 0.15 & 6.2 & 13 \\
\hline \multirow[t]{5}{*}{ GA-17 } & $\mathrm{A}$ & 350 & 3 & $5 \%$ micro-Gt in calcite & $2: 1$ & 1.70 & 0.687 & 0.40 & 26 & 37 \\
\hline & $\mathrm{B}$ & 350 & 3 & $1 \%$ micro-Gt in calcite & $2: 1$ & 0.342 & 0.129 & 0.38 & 17 & 37 \\
\hline & $\mathrm{C}$ & 350 & 3 & $5 \%$ micro-Hm in calcite & $2: 1$ & 0.554 & 0.197 & 0.36 & 28 & 12 \\
\hline & $\mathrm{D}$ & 350 & 3 & $1 \%$ micro-Hm in calcite & $2: 1$ & 0.206 & $6.54 \times 10^{-2}$ & 0.32 & 23 & 22 \\
\hline & $\mathrm{E}$ & 350 & 3 & $1 \%$ nano-Gt in calcite & $2: 1$ & 0.211 & $1.04 \times 10^{-2}$ & 0.05 & 1.8 & 23 \\
\hline \multirow[t]{6}{*}{ GA-18 } & $\mathrm{A}$ & 325 & 64 & $5 \%$ micro-Gt in calcite & $2: 1$ & 1.716 & 0.715 & 0.42 & 27 & 37 \\
\hline & $\mathrm{B}$ & 325 & 64 & $1 \%$ micro-Gt in calcite & $2: 1$ & 0.295 & 0.119 & 0.41 & 22 & 32 \\
\hline & $\mathrm{C}$ & 325 & 64 & $5 \%$ micro-Hm in calcite & $2: 1$ & 0.896 & 0.316 & 0.35 & 30 & 19 \\
\hline & $\mathrm{D}$ & 325 & 64 & $1 \%$ micro-Hm in calcite & $2: 1$ & 0.153 & 0.054 & 0.35 & 27 & 17 \\
\hline & $\mathrm{E}$ & 325 & 64 & $1 \%$ GA-16D in calcite & $2: 1$ & 0.448 & 0.184 & 0.41 & 24 & 49 \\
\hline & $\mathrm{F}$ & 325 & 64 & $1 \%$ nano-Gt in calcite & $2: 1$ & 0.206 & 0.014 & 0.07 & 3.0 & 22 \\
\hline
\end{tabular}



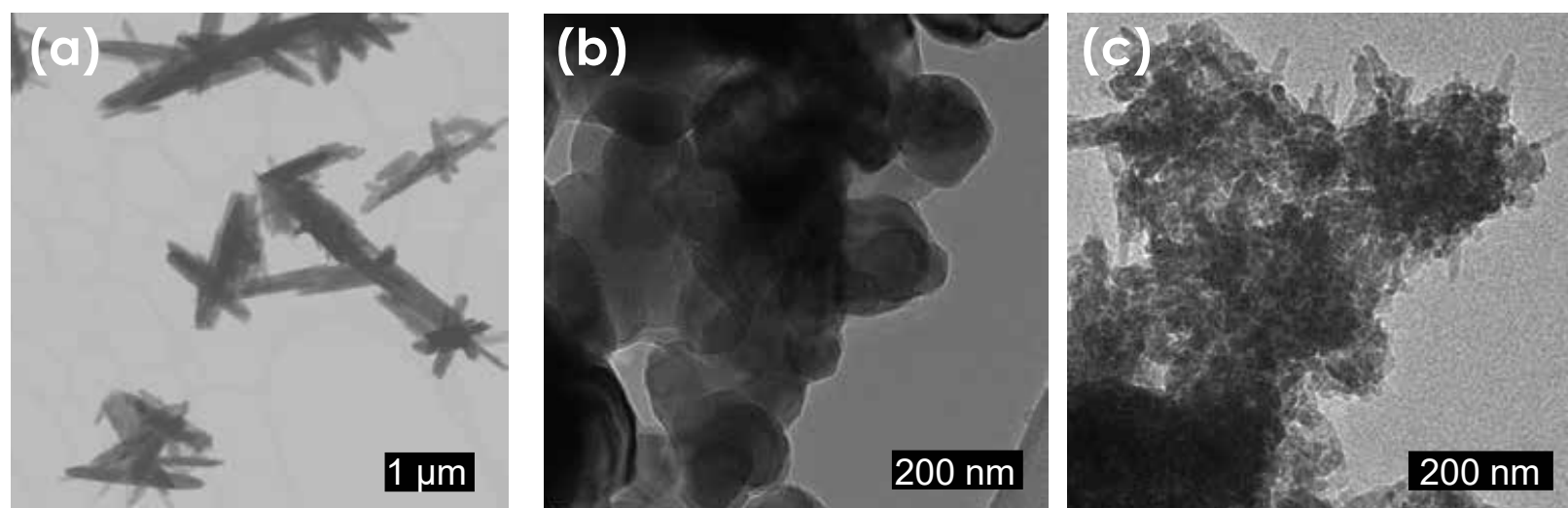

Figure 1. TEM images of starting materials. (a) Micro-goethite pigment; (b) micro-hematite pigment; (c) synthetic nano-goethite aggregates. 

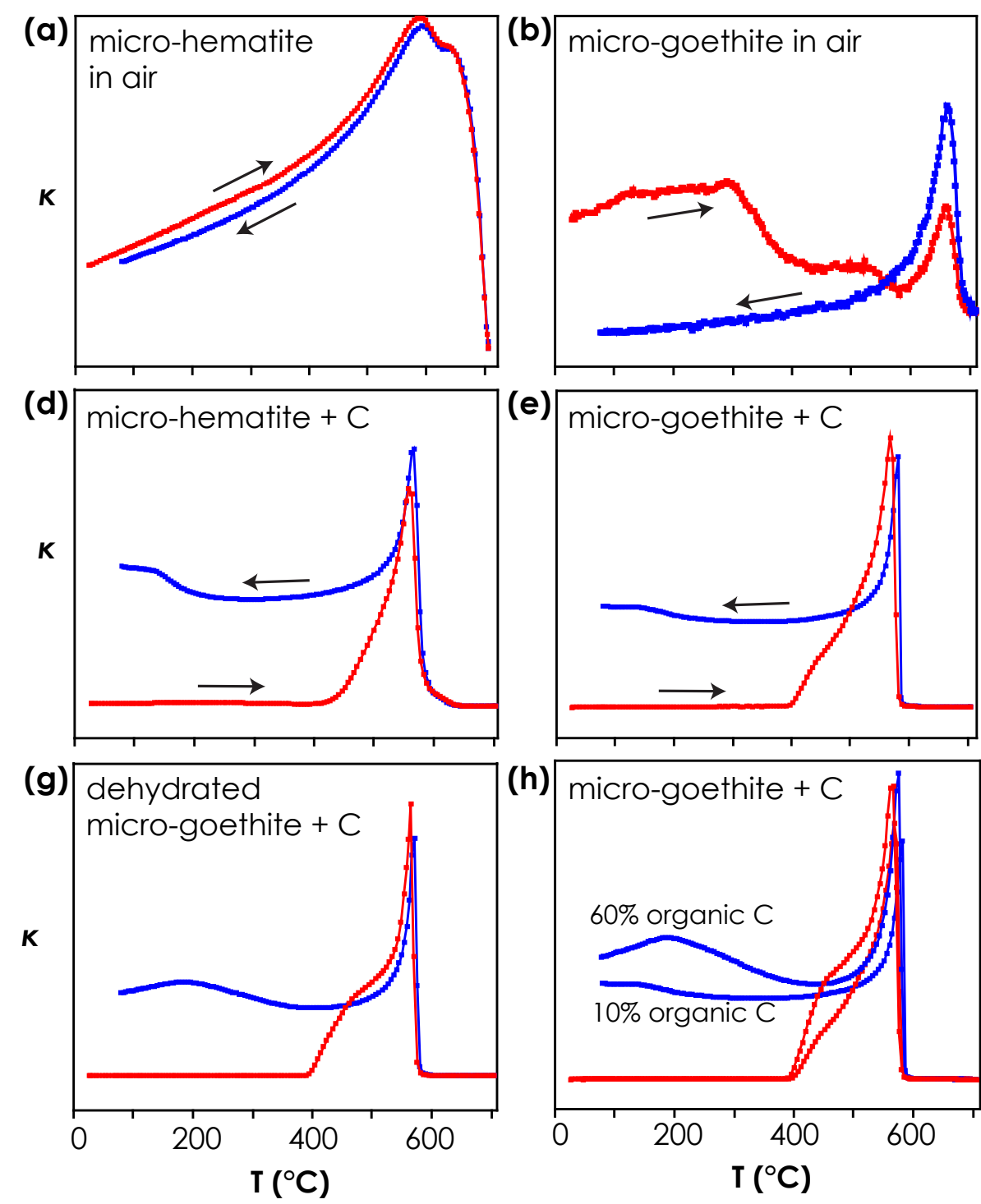

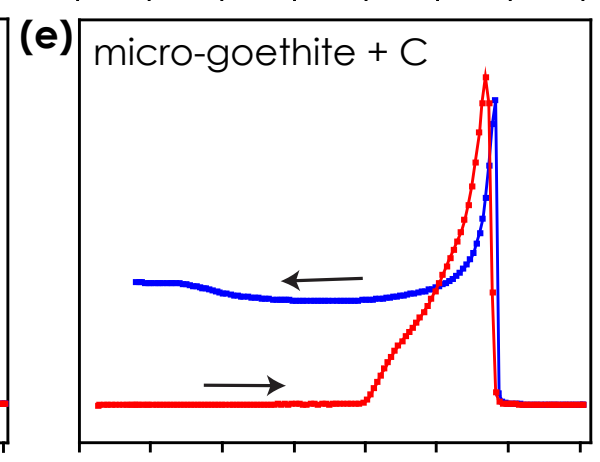

(h)

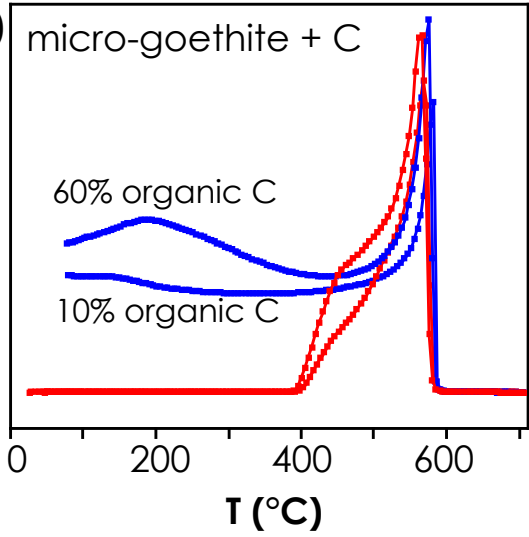

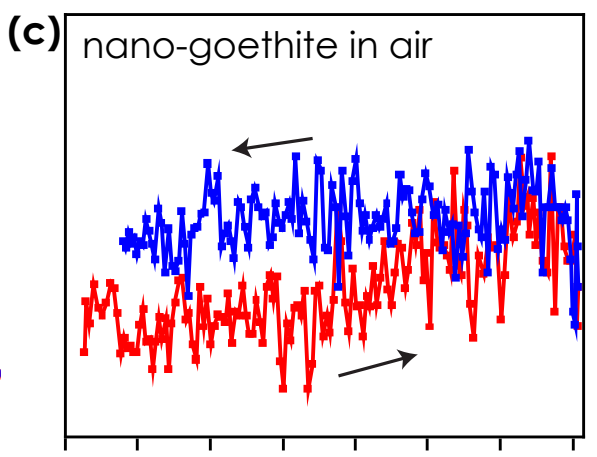

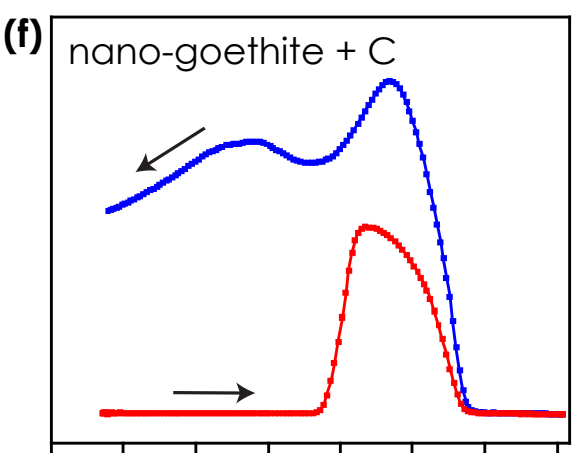

(i)

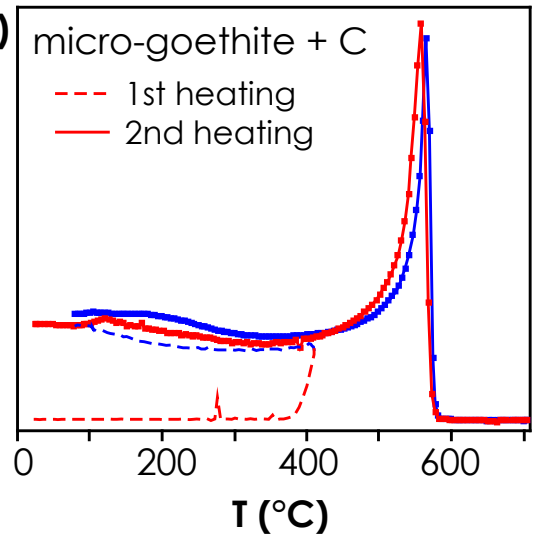

Figure 2. Thermomagnetic curves of magnetic susceptibility for goethite and hematite samples heated with and without organic carbon. Red and blue lines indicate heating and cooling curves, respectively. (a-c) Pure hematite and goethite samples heated in air. (d-f) Hematite and goethite samples mixed with organic C. (g) Nanocrystalline hematite formed from previously heated and dehydrated micro-goethite mixed with organic C. (h) Comparison of micro-goethite mixed with different proportions of organic C. (i) Thermal cycling of micro-goethite mixed with organic C heated to $400^{\circ} \mathrm{C}$ then $700^{\circ} \mathrm{C}$. 

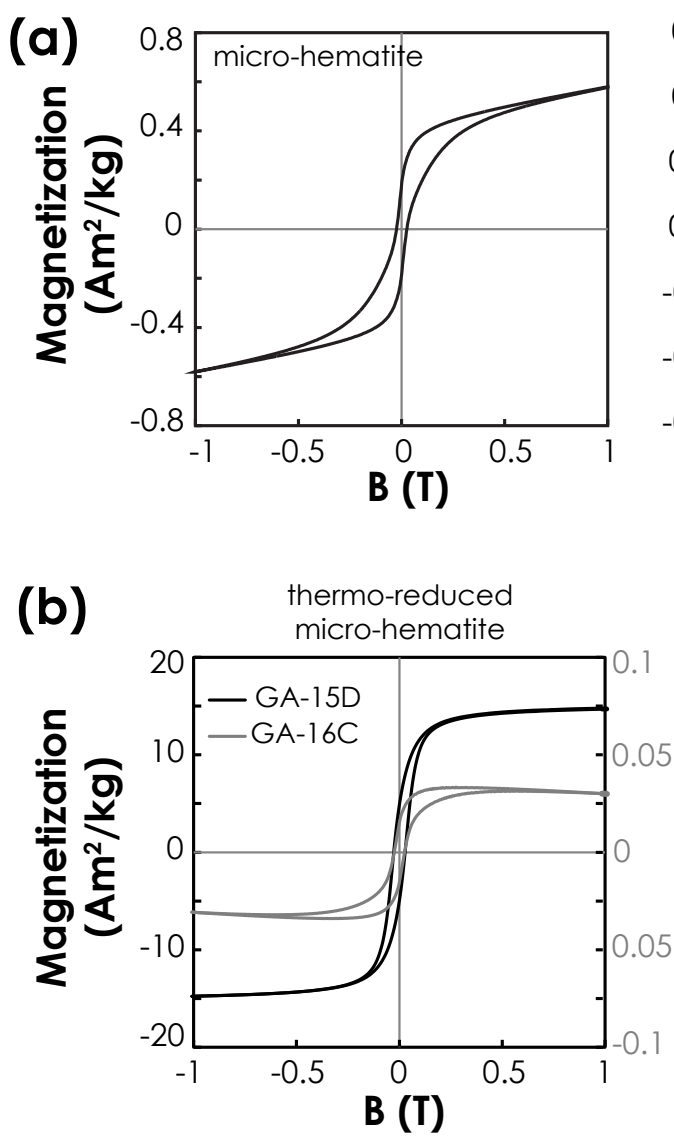
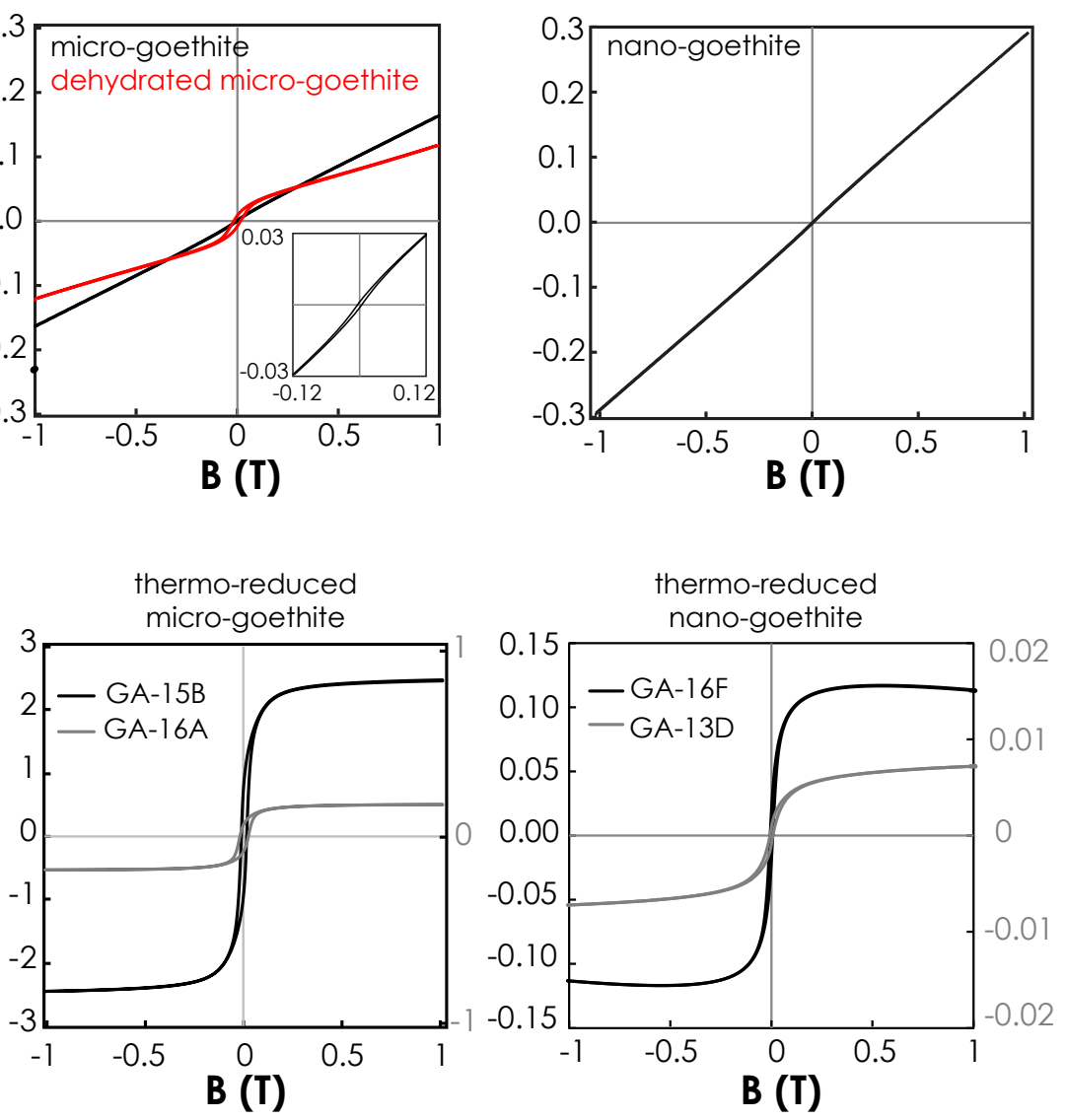
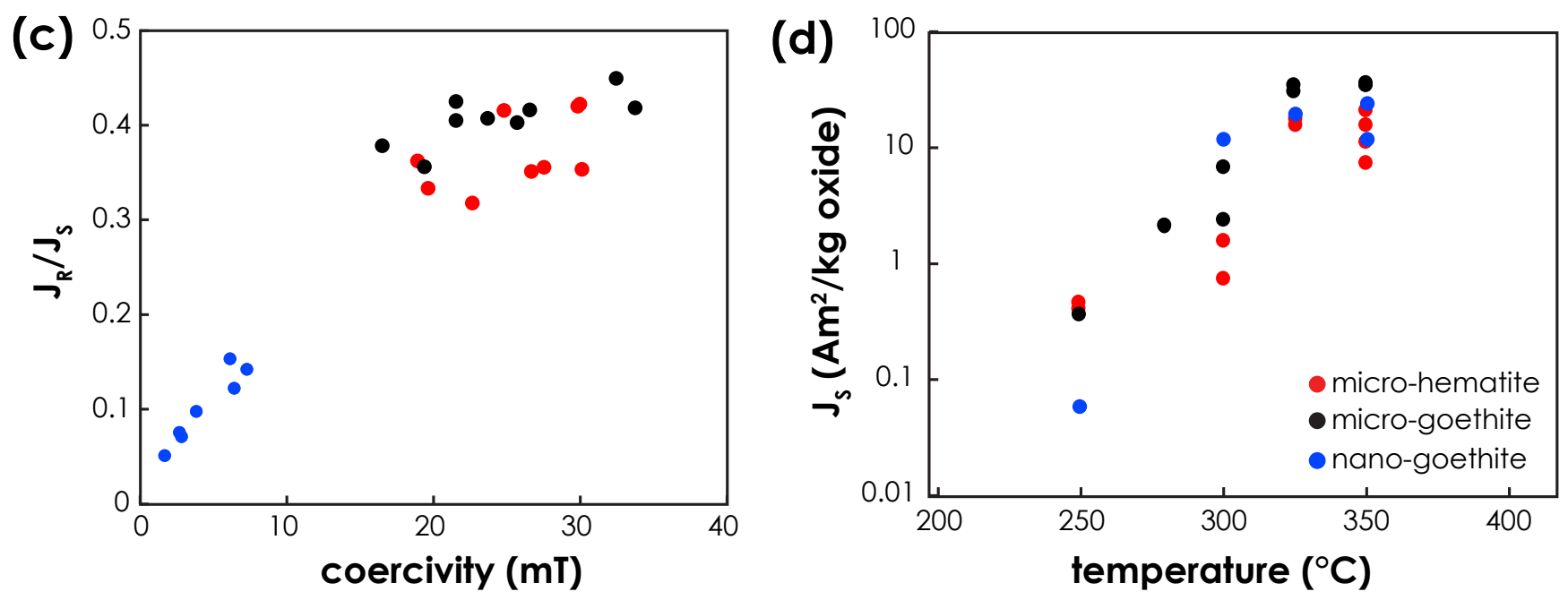

Figure 3. (a) Hysteresis loops of goethite and hematite starting materials. (b) Hysteresis loops of thermo-reduced goethite and hematite samples from representative capsule heating experiments. (c) Squareness plot of hysteresis parameters for capsule heating experiments. (d) Saturation magnetization as a function of heating temperature normalized by initial mass of goethite or hematite in capsule experiments. 

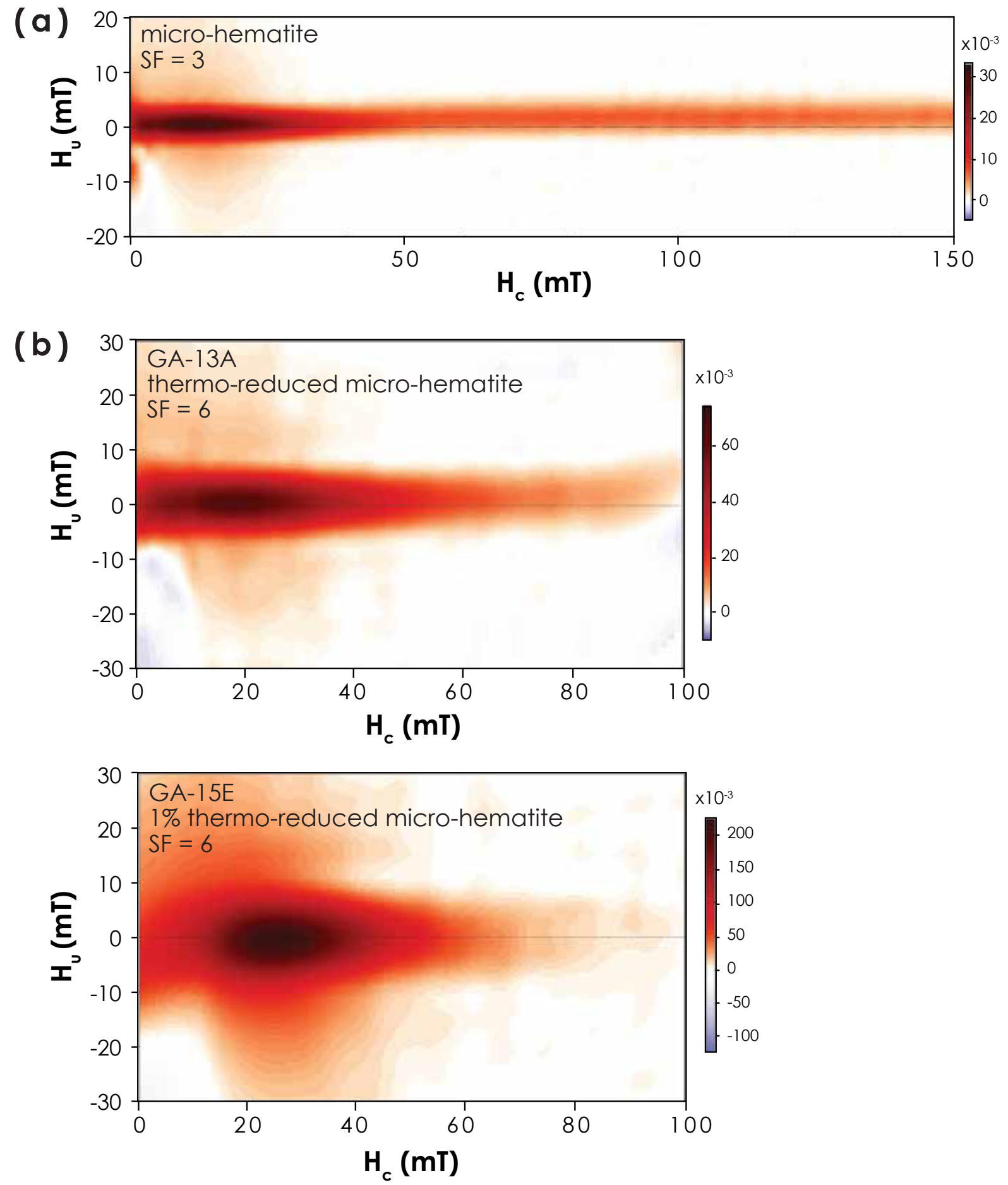

Figure 4. FORC diagrams for micro-hematite and thermo-reduced micro-hematite from selected capsule heating experiments. Smoothing factor (SF) values used for processing FORC data are indicated in each diagram. 


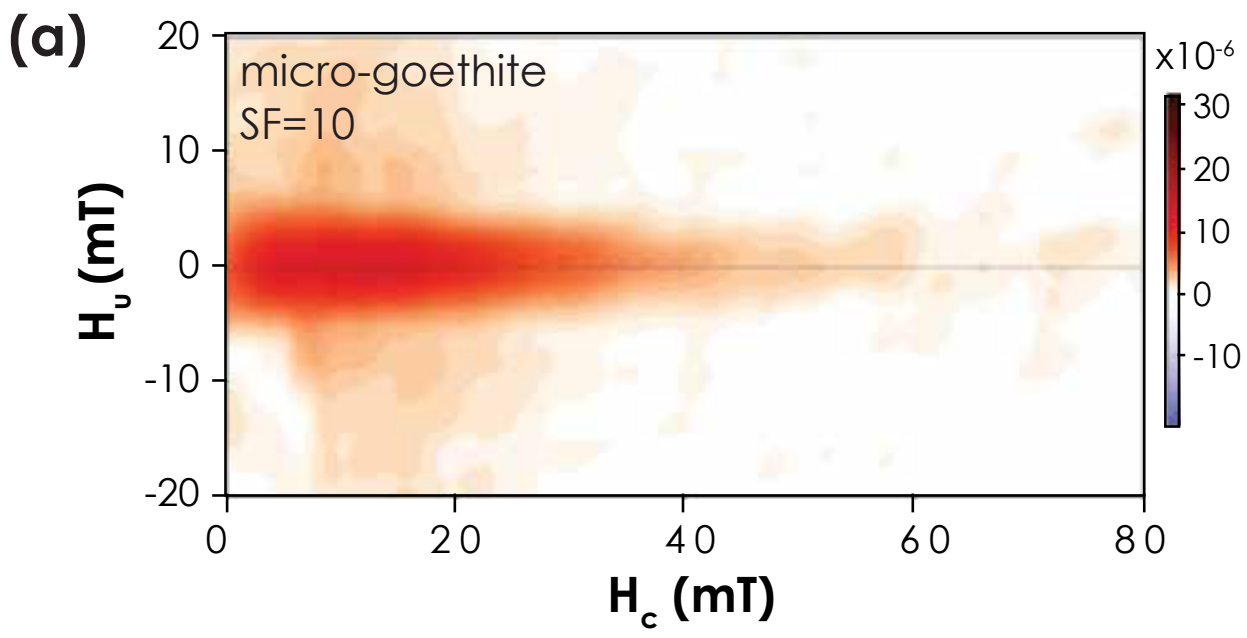

(b)
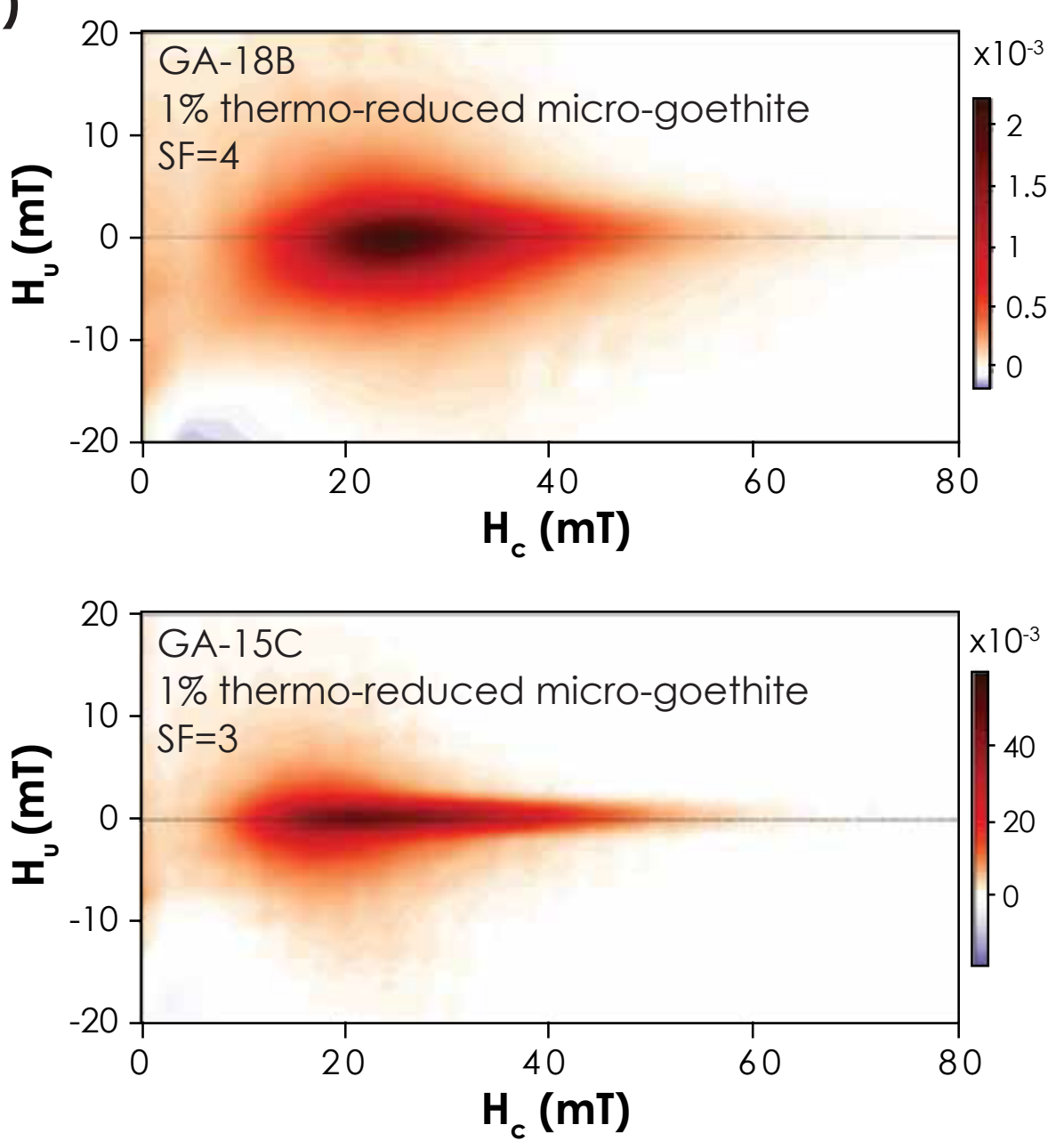

Figure 5. FORC diagrams for micro-goethite and thermo-reduced micro-goethite from selected capsule heating experiments with smoothing factor (SF) values indicated. 

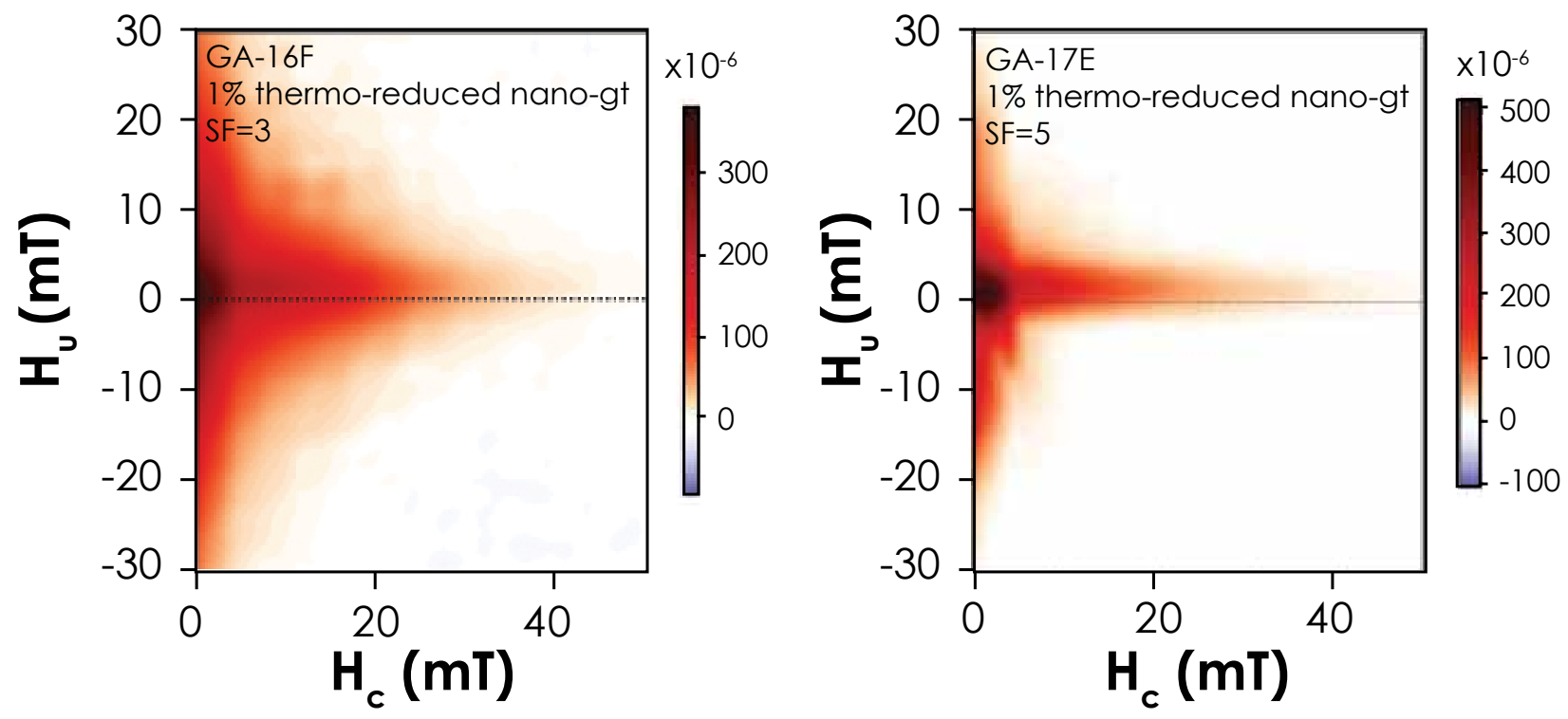

Figure 6. FORC diagrams of thermo-reduced nano-goethite from selected capsule heating experiments with smoothing factor $(\mathrm{SF})$ values indicated. 

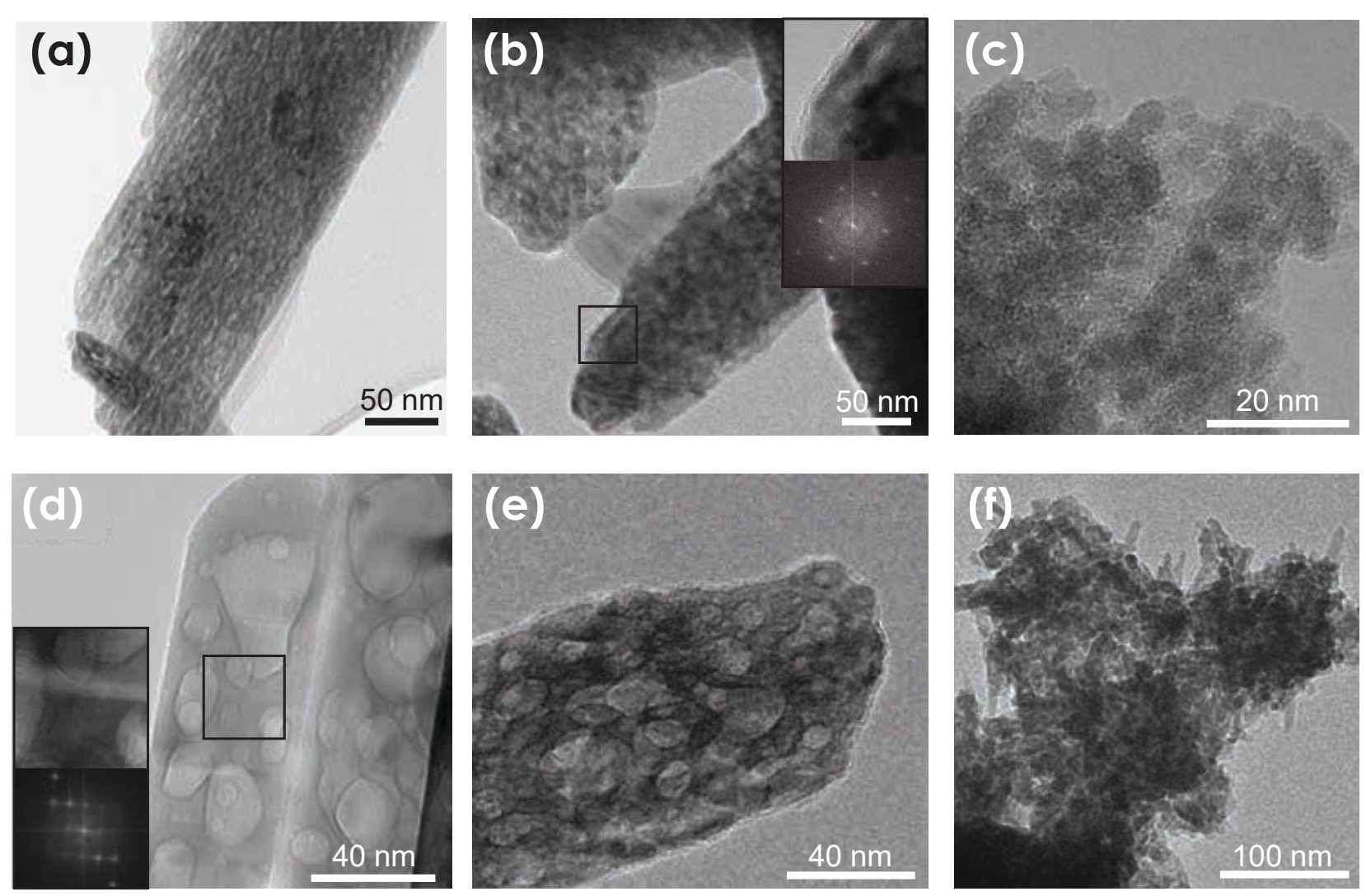

Figure 7. TEM images of heated micro-goethite and nano-goethite. (a) Micro-goethite, heated with organic $\mathrm{C}$ at $275^{\circ} \mathrm{C}$ for $22 \mathrm{~h}$. (b) Micro-goethite heated with organic $\mathrm{C}$ at $350^{\circ} \mathrm{C}$ for $3 \mathrm{~h}$. (c) Nano-goethite heated with organic $\mathrm{C}$ to $700^{\circ} \mathrm{C}$ in the Kappabridge (d) Micro-goethite heated in air to $700^{\circ} \mathrm{C}$ in the Kappabridge. (e) Micro-goethite heated at $350^{\circ} \mathrm{C}$ for $64 \mathrm{~h}$. (f) Nano-goethite heated with organic $\mathrm{C}$ at $360^{\circ} \mathrm{C}$ for $62 \mathrm{~h}$. Insets in (b) and (d) are HRTEM images of the areas within the black squares along with simulated electron diffraction patterns. 

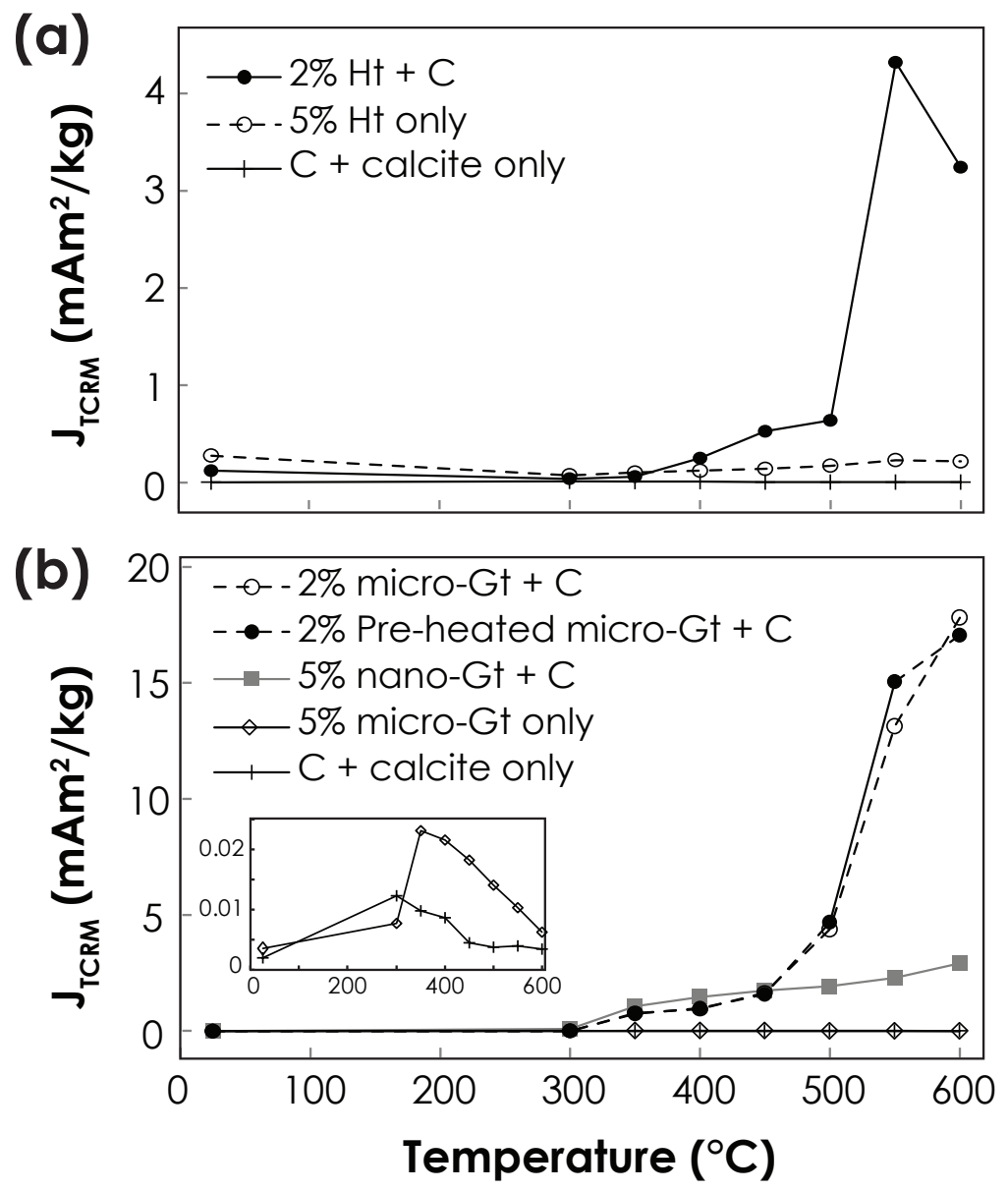

Figure 8. TCRM acquisition curves illustrating the evolution of total magnetization intensity with progressive heating for (a) micro-hematite and calcite mixtures with and without organic carbon, and (b) mixtures of nano-goethite and micro-goethite with and without organic carbon. Room-temperature remanence values are anhysteretic remanent magnetizations. Data for control samples containing only calcite and organic carbon are also shown. The inset in (b) is plotted on an expanded vertical scale. 
$2 \%$ micro-Ht+ C

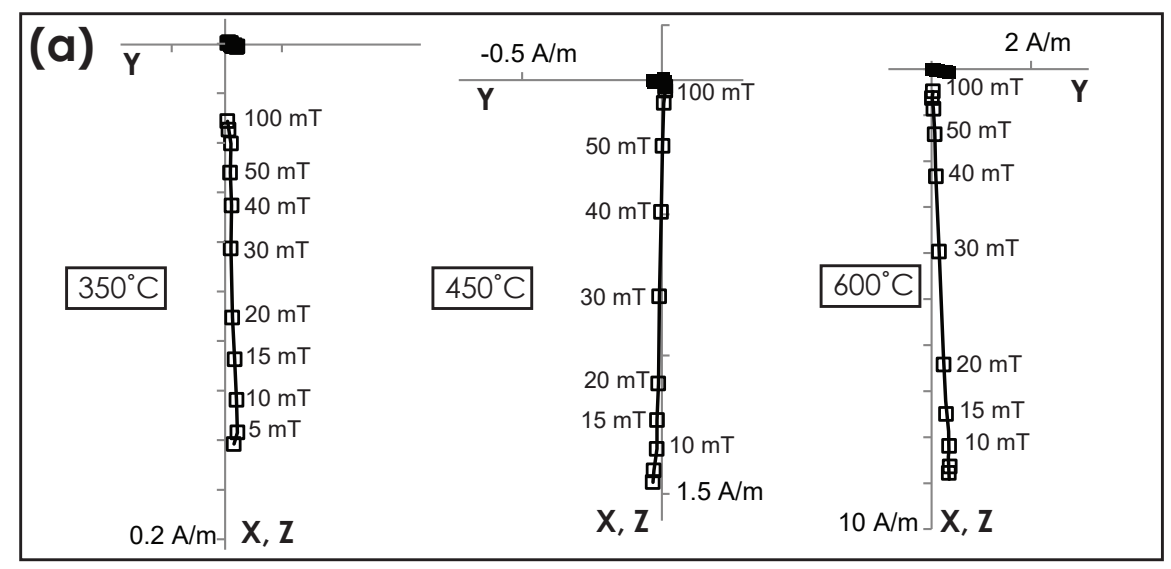

$2 \%$ micro-G $++\mathrm{C}$

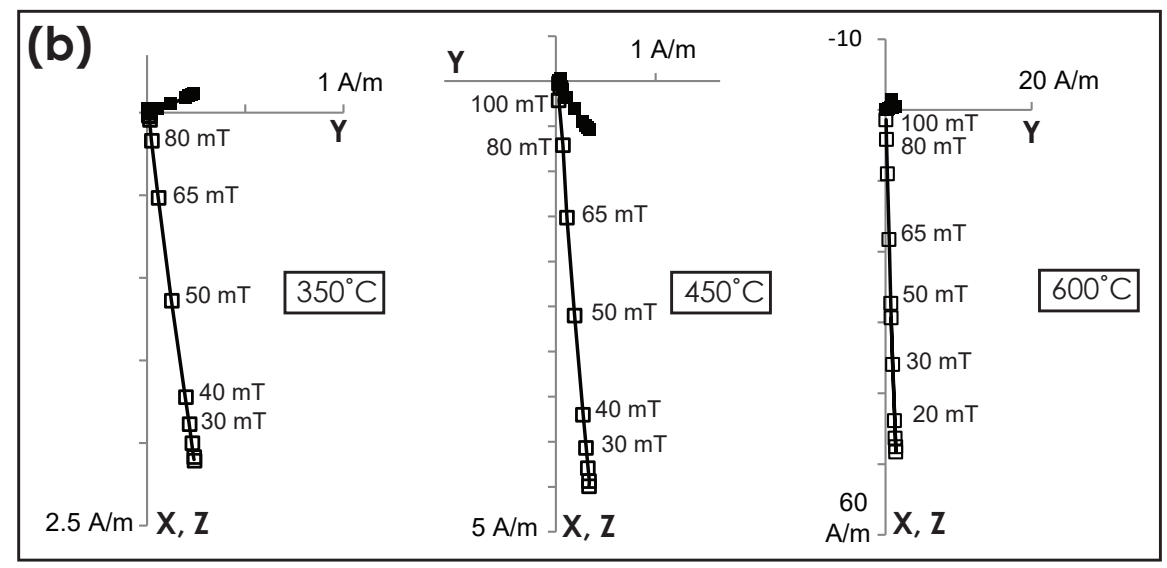

$5 \%$ nano-Gt+ C

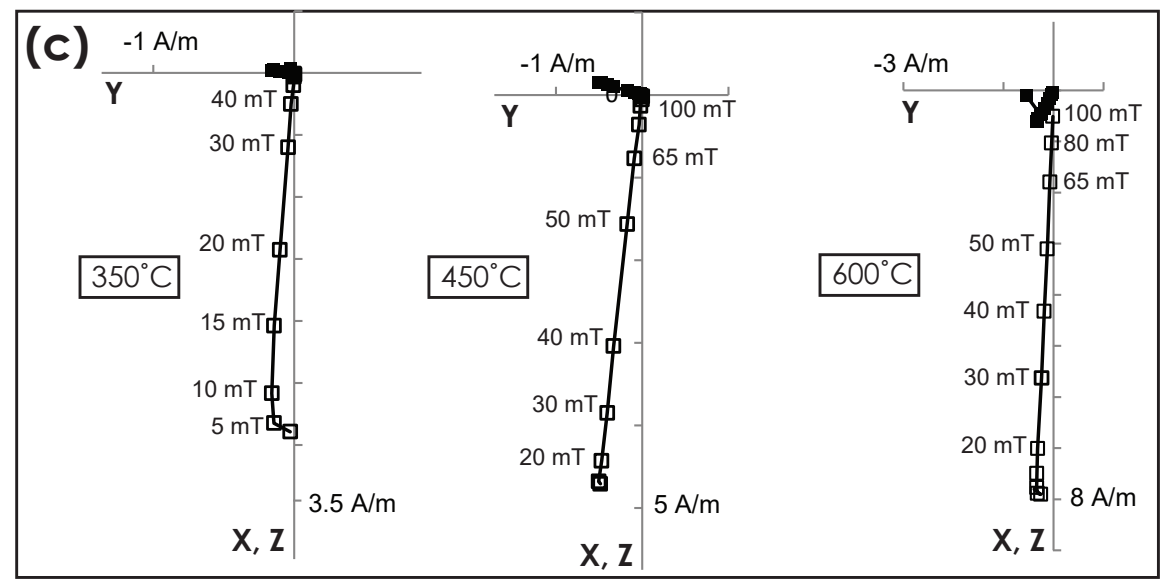

Figure 9. Orthogonal vector diagrams showing AF demagnetization behavior of TCRM acquired by organic carbon-bearing mixtures of calcite containing (a) micro-hematite, (b) micro-goethite and (c) nano-goethite after heating at 350,450 and $600^{\circ} \mathrm{C}$. 

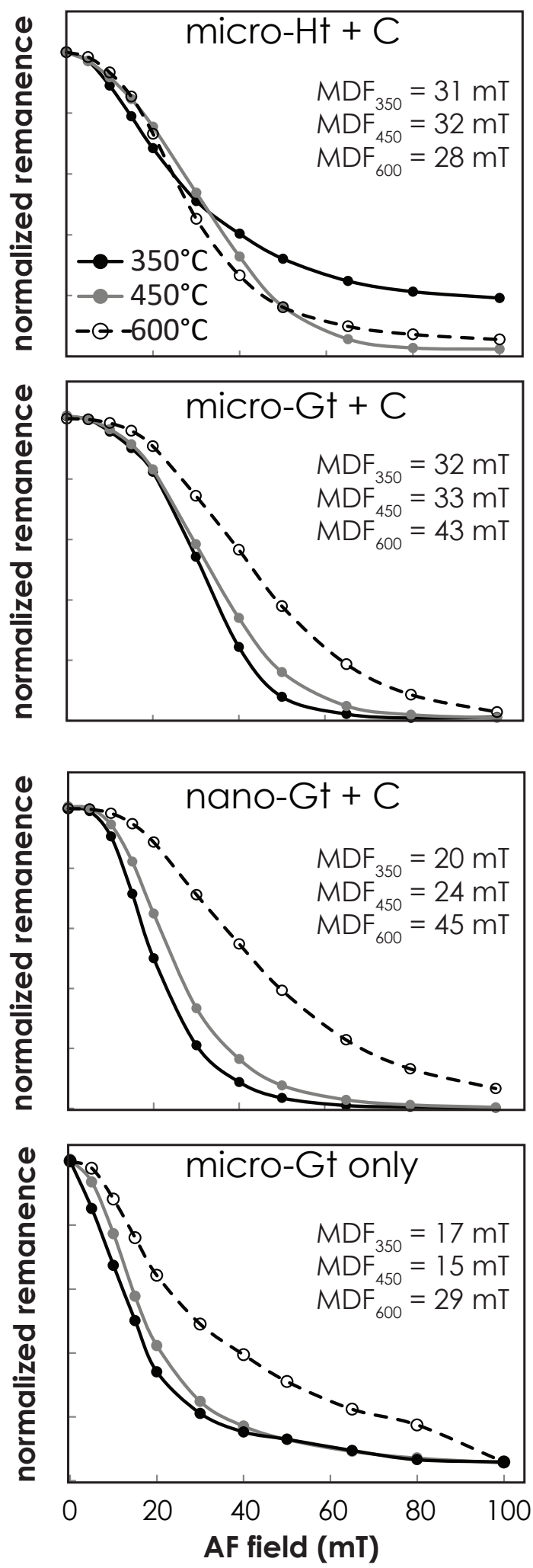

Figure 10. Normalized AF demagnetization spectra of TCRM corresponding to the data plots in Figure 9 as well as demagnetization of TCRMs acquired by micro-goethite heated without organic carbon. Median destructive field (MDF) values interpolated from the data are also indicated. 
Table S1. Remanent magnetization measurements for goethite and hematite samples mixed with sugar and calcite after treatment by alternating field $(\mathrm{AF})$ demagnetization and acquisition of anhysteretic remanent magnetization (ARM) and thermochemical remanent magnetization (TCRM).

\begin{tabular}{|c|c|c|c|c|c|c|}
\hline Sample & Composition & Treatment & $\mathrm{X}\left(\mathrm{mAm}^{2} / \mathrm{kg}\right)$ & $\mathrm{Y}\left(\mathrm{mAm}^{2} / \mathrm{kg}\right)$ & $\mathrm{Z}\left(\mathrm{mAm}^{2} / \mathrm{kg}\right)$ & $\mathrm{J}\left(\mathrm{mAm}^{2} / \mathrm{kg}\right)$ \\
\hline \multirow[t]{9}{*}{ GC06A } & \multirow{9}{*}{$\begin{array}{l}5 \% \text { sugar \& calcite } \\
\text { (control) }\end{array}$} & $\mathrm{AF}$ demag at $100 \mathrm{mT}$ & & & & $1.08 \mathrm{E}-03$ \\
\hline & & ARM & & & & 2.03E-03 \\
\hline & & $\mathrm{TCRM}$ at $300^{\circ} \mathrm{C}$ & $-5.45 \mathrm{E}-05$ & $-3.61 \mathrm{E}-04$ & $1.23 \mathrm{E}-02$ & $1.23 \mathrm{E}-02$ \\
\hline & & $\mathrm{TCRM}$ at $350^{\circ} \mathrm{C}$ & $-3.99 \mathrm{E}-05$ & $8.40 \mathrm{E}-04$ & $9.76 \mathrm{E}-03$ & $9.79 \mathrm{E}-03$ \\
\hline & & TCRM at $400^{\circ} \mathrm{C}$ & $-5.15 \mathrm{E}-03$ & $1.10 \mathrm{E}-04$ & $6.95 \mathrm{E}-03$ & $8.65 \mathrm{E}-03$ \\
\hline & & $\mathrm{TCRM}$ at $450^{\circ} \mathrm{C}$ & $-1.06 \mathrm{E}-03$ & $2.19 \mathrm{E}-04$ & $4.36 \mathrm{E}-03$ & 4.49E-03 \\
\hline & & $\mathrm{TCRM}$ at $500^{\circ} \mathrm{C}$ & $-1.99 \mathrm{E}-04$ & $4.39 \mathrm{E}-04$ & $3.68 \mathrm{E}-03$ & $3.71 \mathrm{E}-03$ \\
\hline & & TCRM at $550^{\circ} \mathrm{C}$ & $-9.93 \mathrm{E}-05$ & $2.39 \mathrm{E}-04$ & $3.98 \mathrm{E}-03$ & $3.99 \mathrm{E}-03$ \\
\hline & & $\mathrm{TCRM}$ at $600^{\circ} \mathrm{C}$ & $-1.48 \mathrm{E}-05$ & $9.73 \mathrm{E}-05$ & $3.42 \mathrm{E}-03$ & $3.42 \mathrm{E}-03$ \\
\hline \multirow[t]{9}{*}{ GC06B } & \multirow{9}{*}{$\begin{array}{l}5 \% \text { micro-goethite \& } \\
\text { calcite (no sugar) }\end{array}$} & $\mathrm{AF}$ demag at $100 \mathrm{mT}$ & & & & $-2.51 \mathrm{E}-04$ \\
\hline & & $\mathrm{ARM}$ & & & & $3.54 \mathrm{E}-03$ \\
\hline & & $\mathrm{TCRM}$ at $300^{\circ} \mathrm{C}$ & $-9.25 \mathrm{E}-04$ & $7.21 \mathrm{E}-04$ & $7.63 \mathrm{E}-03$ & $7.72 \mathrm{E}-03$ \\
\hline & & $\mathrm{TCRM}$ at $350^{\circ} \mathrm{C}$ & $4.65 \mathrm{E}-04$ & $2.01 \mathrm{E}-03$ & $2.31 \mathrm{E}-02$ & $2.31 \mathrm{E}-02$ \\
\hline & & $\mathrm{TCRM}$ at $400^{\circ} \mathrm{C}$ & $-4.20 \mathrm{E}-03$ & $-7.88 \mathrm{E}-05$ & $2.12 \mathrm{E}-02$ & $2.16 \mathrm{E}-02$ \\
\hline & & $\mathrm{TCRM}$ at $450^{\circ} \mathrm{C}$ & $-1.17 \mathrm{E}-03$ & $7.59 \mathrm{E}-04$ & $1.82 \mathrm{E}-02$ & $1.82 \mathrm{E}-02$ \\
\hline & & $\mathrm{TCRM}$ at $500^{\circ} \mathrm{C}$ & $7.04 \mathrm{E}-04$ & $1.47 \mathrm{E}-03$ & $1.40 \mathrm{E}-02$ & $1.41 \mathrm{E}-02$ \\
\hline & & $\mathrm{TCRM}$ at $550^{\circ} \mathrm{C}$ & $1.16 \mathrm{E}-04$ & $3.65 \mathrm{E}-05$ & $1.03 \mathrm{E}-02$ & $1.03 \mathrm{E}-02$ \\
\hline & & $\mathrm{TCRM}$ at $600^{\circ} \mathrm{C}$ & $8.76 \mathrm{E}-05$ & $1.90 \mathrm{E}-04$ & $6.31 \mathrm{E}-03$ & $6.31 \mathrm{E}-03$ \\
\hline \multirow[t]{9}{*}{ GC06C } & \multirow{9}{*}{$\begin{array}{l}5 \% \text { micro-hematite \& } \\
\text { calcite (no sugar) }\end{array}$} & $\mathrm{AF}$ demag at $100 \mathrm{mT}$ & & & & $9.34 \mathrm{E}-04$ \\
\hline & & ARM & & & & $2.76 \mathrm{E}-01$ \\
\hline & & $\mathrm{TCRM}$ at $300^{\circ} \mathrm{C}$ & $-1.26 \mathrm{E}-03$ & $-1.97 \mathrm{E}-03$ & 7.33E-02 & 7.33E-02 \\
\hline & & $\mathrm{TCRM}$ at $350^{\circ} \mathrm{C}$ & $4.78 \mathrm{E}-03$ & $-1.42 \mathrm{E}-03$ & $1.03 \mathrm{E}-01$ & $1.03 \mathrm{E}-01$ \\
\hline & & $\mathrm{TCRM}$ at $400^{\circ} \mathrm{C}$ & $-9.73 \mathrm{E}-03$ & $-3.89 \mathrm{E}-03$ & $1.21 \mathrm{E}-01$ & $1.22 \mathrm{E}-01$ \\
\hline & & $\mathrm{TCRM}$ at $450^{\circ} \mathrm{C}$ & $1.60 \mathrm{E}-03$ & $-5.72 \mathrm{E}-03$ & $1.41 \mathrm{E}-01$ & $1.41 \mathrm{E}-01$ \\
\hline & & $\mathrm{TCRM}$ at $500^{\circ} \mathrm{C}$ & $-1.16 \mathrm{E}-02$ & $1.63 \mathrm{E}-02$ & $1.71 \mathrm{E}-01$ & $1.73 \mathrm{E}-01$ \\
\hline & & $\mathrm{TCRM}$ at $550^{\circ} \mathrm{C}$ & $6.87 \mathrm{E}-03$ & $5.00 \mathrm{E}-03$ & $2.29 \mathrm{E}-01$ & $2.30 \mathrm{E}-01$ \\
\hline & & $\mathrm{TCRM}$ at $600^{\circ} \mathrm{C}$ & $-6.56 \mathrm{E}-03$ & $9.82 \mathrm{E}-03$ & $2.17 \mathrm{E}-01$ & $2.17 \mathrm{E}-01$ \\
\hline \multirow[t]{9}{*}{ GC06D } & \multirow{9}{*}{$\begin{array}{l}2 \% \text { micro-hematite, } 5 \% \\
\text { sugar \& calcite }\end{array}$} & $\mathrm{AF}$ demag at $100 \mathrm{mT}$ & & & & $5.67 \mathrm{E}-04$ \\
\hline & & $\mathrm{ARM}$ & & & & $1.22 \mathrm{E}-01$ \\
\hline & & $\mathrm{TCRM}$ at $300^{\circ} \mathrm{C}$ & $9.65 \mathrm{E}-04$ & $5.00 \mathrm{E}-04$ & $3.84 \mathrm{E}-02$ & $3.84 \mathrm{E}-02$ \\
\hline & & $\mathrm{TCRM}$ at $350^{\circ} \mathrm{C}$ & $2.79 \mathrm{E}-04$ & $1.88 \mathrm{E}-03$ & $5.96 \mathrm{E}-02$ & $5.96 \mathrm{E}-02$ \\
\hline & & $\mathrm{TCRM}$ at $400^{\circ} \mathrm{C}$ & $-1.83 \mathrm{E}-02$ & $-1.74 \mathrm{E}-03$ & $2.50 \mathrm{E}-01$ & $2.51 \mathrm{E}-01$ \\
\hline & & TCRM at $450^{\circ} \mathrm{C}$ & $-5.30 \mathrm{E}-03$ & $-1.10 \mathrm{E}-02$ & $5.26 \mathrm{E}-01$ & $5.26 \mathrm{E}-01$ \\
\hline & & TCRM at $500^{\circ} \mathrm{C}$ & $-5.41 \mathrm{E}-03$ & $6.57 \mathrm{E}-03$ & $6.38 \mathrm{E}-01$ & $6.38 \mathrm{E}-01$ \\
\hline & & $\mathrm{TCRM}$ at $550^{\circ} \mathrm{C}$ & $-2.07 \mathrm{E}-02$ & $7.24 \mathrm{E}-02$ & $4.32 \mathrm{E}+00$ & $4.32 \mathrm{E}+00$ \\
\hline & & TCRM at $600^{\circ} \mathrm{C}$ & $2.69 \mathrm{E}-02$ & $1.36 \mathrm{E}-01$ & $3.24 \mathrm{E}+00$ & $3.24 \mathrm{E}+00$ \\
\hline \multirow[t]{9}{*}{ GC06E } & \multirow{9}{*}{$\begin{array}{l}2 \% \text { micro-goethite, } 5 \% \\
\text { sugar \& calcite }\end{array}$} & $\mathrm{AF}$ demag at $100 \mathrm{mT}$ & & & & $-1.09 \mathrm{E}-04$ \\
\hline & & $\mathrm{ARM}$ & & & & $3.04 \mathrm{E}-03$ \\
\hline & & $\mathrm{TCRM}$ at $300^{\circ} \mathrm{C}$ & $1.57 \mathrm{E}-04$ & $-6.16 \mathrm{E}-04$ & $6.45 \mathrm{E}-03$ & $6.48 \mathrm{E}-03$ \\
\hline & & $\mathrm{TCRM}$ at $350^{\circ} \mathrm{C}$ & $-4.27 \mathrm{E}-02$ & $8.86 \mathrm{E}-02$ & $7.77 \mathrm{E}-01$ & 7.83E-01 \\
\hline & & $\mathrm{TCRM}$ at $400^{\circ} \mathrm{C}$ & $-9.27 \mathrm{E}-02$ & $-2.83 \mathrm{E}-02$ & $9.40 \mathrm{E}-01$ & $9.45 \mathrm{E}-01$ \\
\hline & & TCRM at $450^{\circ} \mathrm{C}$ & $1.96 \mathrm{E}-01$ & $1.23 \mathrm{E}-01$ & $1.64 \mathrm{E}+00$ & $1.66 \mathrm{E}+00$ \\
\hline & & $\mathrm{TCRM}$ at $500^{\circ} \mathrm{C}$ & $2.15 \mathrm{E}-01$ & $-2.43 \mathrm{E}-02$ & $4.39 \mathrm{E}+00$ & $4.39 \mathrm{E}+00$ \\
\hline & & $\mathrm{TCRM}$ at $550^{\circ} \mathrm{C}$ & $6.28 \mathrm{E}-01$ & $6.62 \mathrm{E}-01$ & $1.31 \mathrm{E}+01$ & $1.31 \mathrm{E}+01$ \\
\hline & & $\mathrm{TCRM}$ at $600^{\circ} \mathrm{C}$ & $-5.36 \mathrm{E}-01$ & $2.64 \mathrm{E}-01$ & $1.78 \mathrm{E}+01$ & $1.78 \mathrm{E}+01$ \\
\hline \multirow[t]{9}{*}{ GC06F } & \multirow{9}{*}{$\begin{array}{l}5 \% \text { dehydrated micro- } \\
\text { goethite, } 10 \% \text { sugar \& } \\
\text { calcite }\end{array}$} & $\mathrm{AF}$ demag at $100 \mathrm{mT}$ & & & & $1.16 \mathrm{E}-05$ \\
\hline & & ARM & & & & $1.38 \mathrm{E}-03$ \\
\hline & & $\mathrm{TCRM}$ at $300^{\circ} \mathrm{C}$ & $4.55 \mathrm{E}-06$ & $-1.63 \mathrm{E}-04$ & $3.37 \mathrm{E}-03$ & $3.38 \mathrm{E}-03$ \\
\hline & & $\mathrm{TCRM}$ at $350^{\circ} \mathrm{C}$ & $1.51 \mathrm{E}-02$ & $-7.85 \mathrm{E}-02$ & $7.40 \mathrm{E}-01$ & $7.44 \mathrm{E}-01$ \\
\hline & & $\mathrm{TCRM}$ at $400^{\circ} \mathrm{C}$ & $2.72 \mathrm{E}-02$ & $-4.01 \mathrm{E}-02$ & $9.84 \mathrm{E}-01$ & $9.85 \mathrm{E}-01$ \\
\hline & & $\mathrm{TCRM}$ at $450^{\circ} \mathrm{C}$ & $4.73 \mathrm{E}-02$ & $-5.09 \mathrm{E}-02$ & $1.59 \mathrm{E}+00$ & $1.59 \mathrm{E}+00$ \\
\hline & & $\mathrm{TCRM}$ at $500^{\circ} \mathrm{C}$ & $1.78 \mathrm{E}-02$ & $-3.60 \mathrm{E}-01$ & $4.67 \mathrm{E}+00$ & $4.69 \mathrm{E}+00$ \\
\hline & & $\mathrm{TCRM}$ at $550^{\circ} \mathrm{C}$ & $1.94 \mathrm{E}-01$ & $-6.47 \mathrm{E}-01$ & $1.50 \mathrm{E}+01$ & $1.51 \mathrm{E}+01$ \\
\hline & & $\mathrm{TCRM}$ at $600^{\circ} \mathrm{C}$ & $-4.06 \mathrm{E}-01$ & $4.90 \mathrm{E}-01$ & $1.71 \mathrm{E}+01$ & $1.71 \mathrm{E}+01$ \\
\hline \multirow[t]{9}{*}{ GC06G } & \multirow{9}{*}{$\begin{array}{l}5 \% \text { nano-goethite, } 10 \% \\
\text { sugar \& calcite }\end{array}$} & $\mathrm{AF}$ demag at $100 \mathrm{mT}$ & & & & $2.18 \mathrm{E}-04$ \\
\hline & & $\mathrm{ARM}$ & & & & $2.50 \mathrm{E}-03$ \\
\hline & & $\mathrm{TCRM}$ at $300^{\circ} \mathrm{C}$ & $-1.24 \mathrm{E}-03$ & $-2.14 \mathrm{E}-03$ & $9.34 \mathrm{E}-02$ & $9.34 \mathrm{E}-02$ \\
\hline & & $\mathrm{TCRM}$ at $350^{\circ} \mathrm{C}$ & $-1.17 \mathrm{E}-02$ & $-1.05 \mathrm{E}-02$ & $1.07 \mathrm{E}+00$ & $1.07 \mathrm{E}+00$ \\
\hline & & $\mathrm{TCRM}$ at $400^{\circ} \mathrm{C}$ & 8.99E-02 & $-4.20 \mathrm{E}-02$ & $1.47 \mathrm{E}+00$ & $1.47 \mathrm{E}+00$ \\
\hline & & $\mathrm{TCRM}$ at $450^{\circ} \mathrm{C}$ & $-5.41 \mathrm{E}-02$ & $-1.82 \mathrm{E}-01$ & $1.75 \mathrm{E}+00$ & $1.76 \mathrm{E}+00$ \\
\hline & & $\mathrm{TCRM}$ at $500^{\circ} \mathrm{C}$ & $1.67 \mathrm{E}-01$ & $-1.41 \mathrm{E}-02$ & $1.93 \mathrm{E}+00$ & $1.93 \mathrm{E}+00$ \\
\hline & & TCRM at $550^{\circ} \mathrm{C}$ & $-4.25 \mathrm{E}-02$ & $-1.89 \mathrm{E}-01$ & $2.29 \mathrm{E}+00$ & $2.29 \mathrm{E}+00$ \\
\hline & & $\mathrm{TCRM}$ at $600^{\circ} \mathrm{C}$ & $3.54 \mathrm{E}-02$ & $-2.00 \mathrm{E}-01$ & $2.92 \mathrm{E}+00$ & $2.92 \mathrm{E}+00$ \\
\hline
\end{tabular}




\section{J.L. Till and N.R. Nowaczyk}

Table S2. Progressive alternating field (AF) demagnetization of thermochemical remanent magnetization (TCRM) acquired at 350,450 and $600^{\circ} \mathrm{C}$.

\begin{tabular}{|c|c|c|c|c|c|c|c|c|}
\hline Sample & $\begin{array}{l}\text { TCRM } \\
\left({ }^{\circ} \mathrm{C}\right)\end{array}$ & $\begin{array}{l}\text { Peak AF } \\
\text { field }(\mathrm{mT})\end{array}$ & $\begin{array}{l}\mathrm{X} \\
(\mathrm{mA} / \mathrm{m})\end{array}$ & $\begin{array}{l}\mathrm{Y} \\
(\mathrm{mA} / \mathrm{m})\end{array}$ & $\begin{array}{l}\mathrm{Z} \\
(\mathrm{mA} / \mathrm{m})\end{array}$ & $\begin{array}{l}\mathrm{J} \\
\left(\mathrm{mAm}^{2} / \mathrm{kg}\right)\end{array}$ & $\begin{array}{l}\text { Inc } \\
\left({ }^{\circ}\right)\end{array}$ & $\begin{array}{l}\text { Dec } \\
\left({ }^{\circ}\right)\end{array}$ \\
\hline \multirow[t]{11}{*}{ GC06A } & \multirow[t]{11}{*}{350} & 0 & $-7.64 \mathrm{E}-02$ & $2.30 \mathrm{E}+00$ & $2.66 \mathrm{E}+01$ & $9.84 \mathrm{E}-03$ & 85.1 & 91.9 \\
\hline & & 5 & $1.26 \mathrm{E}-01$ & $2.09 \mathrm{E}+00$ & $2.52 \mathrm{E}+01$ & $9.32 \mathrm{E}-03$ & 85.3 & 86.5 \\
\hline & & 10 & $1.98 \mathrm{E}-01$ & $1.84 \mathrm{E}+00$ & $2.20 \mathrm{E}+01$ & $8.15 \mathrm{E}-03$ & 85.2 & 83.9 \\
\hline & & 15 & $3.71 \mathrm{E}-01$ & $2.06 \mathrm{E}+00$ & $1.78 \mathrm{E}+01$ & $6.60 \mathrm{E}-03$ & 83.3 & 79.8 \\
\hline & & 20 & $3.22 \mathrm{E}-02$ & $1.94 \mathrm{E}+00$ & $1.42 \mathrm{E}+01$ & $5.28 \mathrm{E}-03$ & 82.2 & 89 \\
\hline & & 30 & $-9.14 \mathrm{E}-01$ & $1.55 \mathrm{E}+00$ & $9.11 \mathrm{E}+00$ & $3.43 \mathrm{E}-03$ & 78.8 & 120.5 \\
\hline & & 40 & $6.01 \mathrm{E}-02$ & $3.39 \mathrm{E}-01$ & $6.10 \mathrm{E}+00$ & $2.25 \mathrm{E}-03$ & 86.8 & 80 \\
\hline & & 50 & $6.69 \mathrm{E}-01$ & $5.58 \mathrm{E}-01$ & $4.27 \mathrm{E}+00$ & $1.61 \mathrm{E}-03$ & 78.5 & 39.8 \\
\hline & & 65 & $-7.79 \mathrm{E}-01$ & $9.98 \mathrm{E}-01$ & $3.15 \mathrm{E}+00$ & $1.25 \mathrm{E}-03$ & 68.1 & 128 \\
\hline & & 80 & $-5.63 \mathrm{E}-01$ & $1.00 \mathrm{E}+00$ & $2.74 \mathrm{E}+00$ & $1.10 \mathrm{E}-03$ & 67.2 & 119.3 \\
\hline & & 100 & $-9.52 \mathrm{E}-01$ & $1.25 \mathrm{E}-01$ & $1.36 \mathrm{E}+00$ & $6.16 \mathrm{E}-04$ & 54.9 & 172.5 \\
\hline \multirow[t]{11}{*}{ GC06B } & \multirow[t]{11}{*}{350} & 0 & $1.38 \mathrm{E}+00$ & $5.97 \mathrm{E}+00$ & $6.22 \mathrm{E}+01$ & $2.31 \mathrm{E}-02$ & 84.4 & 77 \\
\hline & & 5 & $1.07 \mathrm{E}+00$ & $6.34 \mathrm{E}+00$ & $5.78 \mathrm{E}+01$ & $2.15 \mathrm{E}-02$ & 83.7 & 80.5 \\
\hline & & 10 & $7.82 \mathrm{E}-01$ & $5.46 \mathrm{E}+00$ & $4.78 \mathrm{E}+01$ & $1.77 \mathrm{E}-02$ & 83.4 & 81.9 \\
\hline & & 15 & $9.98 \mathrm{E}-02$ & $3.48 \mathrm{E}+00$ & $3.57 \mathrm{E}+01$ & $1.32 \mathrm{E}-02$ & 84.4 & 88.4 \\
\hline & & 20 & $7.25 \mathrm{E}-01$ & $2.76 \mathrm{E}+00$ & $2.61 \mathrm{E}+01$ & $9.70 \mathrm{E}-03$ & 83.8 & 75.3 \\
\hline & & 30 & $9.04 \mathrm{E}-01$ & $1.27 \mathrm{E}+00$ & $1.53 \mathrm{E}+01$ & $5.69 \mathrm{E}-03$ & 84.2 & 54.6 \\
\hline & & 40 & $4.72 \mathrm{E}-01$ & $-3.79 \mathrm{E}-01$ & $1.06 \mathrm{E}+01$ & $3.92 \mathrm{E}-03$ & 86.7 & -38.7 \\
\hline & & 50 & 4.64E-01 & 7.65E-02 & $8.02 \mathrm{E}+00$ & $2.96 \mathrm{E}-03$ & 86.6 & 9.4 \\
\hline & & 65 & $4.52 \mathrm{E}-01$ & $-9.36 \mathrm{E}-01$ & $5.61 \mathrm{E}+00$ & $2.10 \mathrm{E}-03$ & 79.5 & -64.2 \\
\hline & & 80 & $-6.88 \mathrm{E}-01$ & $-4.38 \mathrm{E}-01$ & $4.35 \mathrm{E}+00$ & $1.63 \mathrm{E}-03$ & 79.4 & 212.5 \\
\hline & & 100 & $-5.86 \mathrm{E}-01$ & $-7.00 \mathrm{E}-01$ & $3.37 \mathrm{E}+00$ & $1.29 \mathrm{E}-03$ & 74.8 & 230 \\
\hline \multirow[t]{11}{*}{ GC06C } & \multirow[t]{11}{*}{350} & 0 & $1.32 \mathrm{E}+01$ & $-3.93 \mathrm{E}+00$ & $2.78 \mathrm{E}+02$ & $1.03 \mathrm{E}-01$ & 87.2 & -16.5 \\
\hline & & 5 & $1.25 \mathrm{E}+01$ & $-3.65 \mathrm{E}+00$ & $2.61 \mathrm{E}+02$ & $9.64 \mathrm{E}-02$ & 87.2 & -16.3 \\
\hline & & 10 & $1.04 \mathrm{E}+01$ & $-2.94 \mathrm{E}+00$ & $2.09 \mathrm{E}+02$ & 7.71E-02 & 87 & -15.7 \\
\hline & & 15 & $8.24 \mathrm{E}+00$ & $-2.13 \mathrm{E}+00$ & $1.61 \mathrm{E}+02$ & $5.95 \mathrm{E}-02$ & 87 & -14.5 \\
\hline & & 20 & $6.44 \mathrm{E}+00$ & $-1.90 \mathrm{E}+00$ & $1.28 \mathrm{E}+02$ & $4.74 \mathrm{E}-02$ & 87 & -16.4 \\
\hline & & 30 & $4.86 \mathrm{E}+00$ & $-2.39 \mathrm{E}+00$ & $9.39 \mathrm{E}+01$ & $3.47 \mathrm{E}-02$ & 86.7 & -26.2 \\
\hline & & 40 & $4.71 \mathrm{E}+00$ & $-2.40 \mathrm{E}+00$ & $7.63 \mathrm{E}+01$ & $2.82 \mathrm{E}-02$ & 86 & -27 \\
\hline & & 50 & $2.19 \mathrm{E}+00$ & $-2.15 \mathrm{E}+00$ & $6.28 \mathrm{E}+01$ & $2.32 \mathrm{E}-02$ & 87.2 & -44.4 \\
\hline & & 65 & $2.45 \mathrm{E}+00$ & $-1.06 \mathrm{E}+00$ & $4.70 \mathrm{E}+01$ & $1.74 \mathrm{E}-02$ & 86.8 & -23.4 \\
\hline & & 80 & $1.92 \mathrm{E}+00$ & $-2.69 \mathrm{E}-01$ & $3.56 \mathrm{E}+01$ & $1.31 \mathrm{E}-02$ & 86.9 & -8 \\
\hline & & 100 & $1.96 \mathrm{E}+00$ & $-7.15 \mathrm{E}-01$ & $2.54 \mathrm{E}+01$ & $9.39 \mathrm{E}-03$ & 85.3 & -20 \\
\hline \multirow[t]{11}{*}{ GC06D } & \multirow[t]{11}{*}{350} & 0 & $6.85 \mathrm{E}-01$ & $3.34 \mathrm{E}+00$ & $1.61 \mathrm{E}+02$ & $5.95 \mathrm{E}-02$ & 88.8 & 78.4 \\
\hline & & 5 & 7.97E-01 & $4.67 \mathrm{E}+00$ & $1.56 \mathrm{E}+02$ & $5.78 \mathrm{E}-02$ & 88.3 & 80.3 \\
\hline & & 10 & $1.03 \mathrm{E}+00$ & $4.30 \mathrm{E}+00$ & $1.43 \mathrm{E}+02$ & $5.29 \mathrm{E}-02$ & 88.2 & 76.5 \\
\hline & & 15 & $2.93 \mathrm{E}-01$ & $3.60 \mathrm{E}+00$ & $1.27 \mathrm{E}+02$ & 4.69E-02 & 88.4 & 85.4 \\
\hline & & 20 & $6.48 \mathrm{E}-01$ & $2.76 \mathrm{E}+00$ & $1.10 \mathrm{E}+02$ & $4.06 \mathrm{E}-02$ & 88.5 & 76.8 \\
\hline & & 30 & $3.46 \mathrm{E}-02$ & $2.17 \mathrm{E}+00$ & $8.23 \mathrm{E}+01$ & $3.04 \mathrm{E}-02$ & 88.5 & 89.1 \\
\hline & & 40 & $2.73 \mathrm{E}-01$ & $2.44 \mathrm{E}+00$ & $6.49 \mathrm{E}+01$ & $2.40 \mathrm{E}-02$ & 87.8 & 83.6 \\
\hline & & 50 & $-5.55 \mathrm{E}-01$ & $1.95 \mathrm{E}+00$ & $5.18 \mathrm{E}+01$ & $1.91 \mathrm{E}-02$ & 87.8 & 105.9 \\
\hline & & 65 & $-5.49 \mathrm{E}-01$ & $2.21 \mathrm{E}+00$ & $4.00 \mathrm{E}+01$ & $1.48 \mathrm{E}-02$ & 86.7 & 104 \\
\hline & & 80 & $-9.34 \mathrm{E}-01$ & $1.35 \mathrm{E}+00$ & $3.43 \mathrm{E}+01$ & $1.27 \mathrm{E}-02$ & 87.3 & 124.8 \\
\hline & & 100 & $-5.63 \mathrm{E}-01$ & $8.78 \mathrm{E}-01$ & $3.09 \mathrm{E}+01$ & $1.14 \mathrm{E}-02$ & 88.1 & 122.7 \\
\hline \multirow[t]{11}{*}{ GC06E } & \multirow[t]{11}{*}{350} & 0 & $-1.15 \mathrm{E}+02$ & $2.38 \mathrm{E}+02$ & $2.10 \mathrm{E}+03$ & $7.81 \mathrm{E}-01$ & 82.8 & 115.7 \\
\hline & & 5 & $-1.14 \mathrm{E}+02$ & $2.35 \mathrm{E}+02$ & $2.08 \mathrm{E}+03$ & 7.73E-01 & 82.8 & 115.8 \\
\hline & & 10 & $-1.08 \mathrm{E}+02$ & $2.26 \mathrm{E}+02$ & $1.99 \mathrm{E}+03$ & $7.42 \mathrm{E}-01$ & 82.8 & 115.5 \\
\hline & & 15 & $-1.01 \mathrm{E}+02$ & $2.13 \mathrm{E}+02$ & $1.88 \mathrm{E}+03$ & $6.99 \mathrm{E}-01$ & 82.9 & 115.3 \\
\hline & & 20 & $-9.01 \mathrm{E}+01$ & $1.94 \mathrm{E}+02$ & $1.72 \mathrm{E}+03$ & $6.38 \mathrm{E}-01$ & 82.9 & 115 \\
\hline & & 30 & $-5.20 \mathrm{E}+01$ & $1.22 \mathrm{E}+02$ & $1.13 \mathrm{E}+03$ & $4.21 \mathrm{E}-01$ & 83.3 & 113 \\
\hline & & 40 & $-2.60 \mathrm{E}+01$ & $5.49 \mathrm{E}+01$ & $5.10 \mathrm{E}+02$ & $1.89 \mathrm{E}-01$ & 83.2 & 115.4 \\
\hline & & 50 & $5.32 \mathrm{E}+00$ & $2.06 \mathrm{E}+01$ & $1.65 \mathrm{E}+02$ & $6.14 \mathrm{E}-02$ & 82.6 & 75.6 \\
\hline & & 65 & $-2.18 \mathrm{E}+01$ & $1.12 \mathrm{E}+01$ & $3.90 \mathrm{E}+01$ & $1.70 \mathrm{E}-02$ & 57.8 & 152.7 \\
\hline & & 80 & $-4.15 \mathrm{E}+00$ & $7.36 \mathrm{E}+00$ & $1.79 \mathrm{E}+01$ & 7.30E-03 & 64.7 & 119.4 \\
\hline & & 100 & $-2.30 \mathrm{E}+01$ & $5.26 \mathrm{E}+00$ & $1.04 \mathrm{E}+01$ & $9.50 \mathrm{E}-03$ & 23.9 & 167.1 \\
\hline \multirow[t]{11}{*}{ GC06F } & 350 & 0 & $1.04 \mathrm{E}+02$ & $-6.38 \mathrm{E}+02$ & $4.98 \mathrm{E}+03$ & $1.85 \mathrm{E}+00$ & 82.6 & -80.8 \\
\hline & & 5 & $1.02 \mathrm{E}+02$ & $-5.82 \mathrm{E}+02$ & $4.92 \mathrm{E}+03$ & $1.83 \mathrm{E}+00$ & 83.2 & -80 \\
\hline & & 10 & $9.77 \mathrm{E}+01$ & $-4.94 \mathrm{E}+02$ & $4.71 \mathrm{E}+03$ & $1.75 \mathrm{E}+00$ & 83.9 & -78.8 \\
\hline & & 15 & $9.21 \mathrm{E}+01$ & $-4.87 \mathrm{E}+02$ & $4.43 \mathrm{E}+03$ & $1.65 \mathrm{E}+00$ & 83.6 & -79.3 \\
\hline & & 20 & $8.69 \mathrm{E}+01$ & $-4.32 \mathrm{E}+02$ & $4.08 \mathrm{E}+03$ & $1.52 \mathrm{E}+00$ & 83.8 & -78.6 \\
\hline & & 30 & $6.98 \mathrm{E}+01$ & $-3.53 \mathrm{E}+02$ & $3.07 \mathrm{E}+03$ & $1.14 \mathrm{E}+00$ & 83.3 & -78.8 \\
\hline & & 40 & $3.77 \mathrm{E}+01$ & $-1.74 \mathrm{E}+02$ & $1.82 \mathrm{E}+03$ & $6.73 \mathrm{E}-01$ & 84.4 & -77.8 \\
\hline & & 50 & $2.21 \mathrm{E}+01$ & $-6.85 \mathrm{E}+01$ & $7.72 \mathrm{E}+02$ & $2.86 \mathrm{E}-01$ & 84.7 & -72.1 \\
\hline & & 65 & $2.93 \mathrm{E}+01$ & $-1.17 \mathrm{E}+01$ & $2.00 \mathrm{E}+02$ & $7.46 \mathrm{E}-02$ & 81 & -21.8 \\
\hline & & 80 & $2.17 \mathrm{E}+00$ & $2.94 \mathrm{E}+00$ & $6.42 \mathrm{E}+01$ & $2.37 \mathrm{E}-02$ & 86.7 & 53.6 \\
\hline & & 100 & $2.77 \mathrm{E}+01$ & $2.22 \mathrm{E}-01$ & $2.65 \mathrm{E}+01$ & $1.41 \mathrm{E}-02$ & 43.8 & 0.5 \\
\hline
\end{tabular}




\begin{tabular}{|c|c|c|c|c|c|c|c|c|}
\hline Sample & $\begin{array}{l}\text { TCRM } \\
\left({ }^{\circ} \mathrm{C}\right)\end{array}$ & $\begin{array}{l}\text { Peak AF } \\
\text { field }(\mathrm{mT})\end{array}$ & $\begin{array}{l}\mathrm{X} \\
(\mathrm{mA} / \mathrm{m})\end{array}$ & $\begin{array}{l}\mathrm{Y} \\
(\mathrm{mA} / \mathrm{m})\end{array}$ & $\begin{array}{l}\mathrm{Z} \\
(\mathrm{mA} / \mathrm{m})\end{array}$ & $\begin{array}{l}\mathrm{J} \\
\left(\mathrm{mAm}^{2} / \mathrm{kg}\right)\end{array}$ & $\begin{array}{l}\text { Inc } \\
\left({ }^{\circ}\right)\end{array}$ & $\begin{array}{l}\text { Dec } \\
\left({ }^{\circ}\right)\end{array}$ \\
\hline \multirow[t]{11}{*}{ GC06G } & \multirow[t]{11}{*}{350} & 0 & $-3.18 \mathrm{E}+01$ & $-2.85 \mathrm{E}+01$ & $2.89 \mathrm{E}+03$ & $1.07 \mathrm{E}+00$ & 89.3 & 234 \\
\hline & & 5 & $-2.64 \mathrm{E}+01$ & $-1.44 \mathrm{E}+02$ & $2.82 \mathrm{E}+03$ & $1.04 \mathrm{E}+00$ & 87 & 259.6 \\
\hline & & 10 & $-2.16 \mathrm{E}+01$ & $-1.60 \mathrm{E}+02$ & $2.58 \mathrm{E}+03$ & $9.55 \mathrm{E}-01$ & 86.4 & 262.3 \\
\hline & & 15 & $-1.62 \mathrm{E}+01$ & $-1.43 \mathrm{E}+02$ & $2.04 \mathrm{E}+03$ & $7.54 \mathrm{E}-01$ & 86 & 263.5 \\
\hline & & 20 & $-9.38 \mathrm{E}+00$ & $-1.02 \mathrm{E}+02$ & $1.43 \mathrm{E}+03$ & $5.27 \mathrm{E}-01$ & 85.9 & 264.7 \\
\hline & & 30 & $-1.30 \mathrm{E}+00$ & $-4.34 \mathrm{E}+01$ & $5.99 \mathrm{E}+02$ & $2.22 \mathrm{E}-01$ & 85.9 & 268.3 \\
\hline & & 40 & $-1.87 \mathrm{E}+00$ & $-2.32 \mathrm{E}+01$ & $2.50 \mathrm{E}+02$ & $9.25 \mathrm{E}-02$ & 84.7 & 265.4 \\
\hline & & 50 & $-6.56 \mathrm{E}-01$ & $-5.36 \mathrm{E}+00$ & $9.90 \mathrm{E}+01$ & $3.66 \mathrm{E}-02$ & 86.9 & 263 \\
\hline & & 65 & $-5.54 \mathrm{E}-01$ & $-2.18 \mathrm{E}+00$ & $2.94 \mathrm{E}+01$ & $1.09 \mathrm{E}-02$ & 85.6 & 255.8 \\
\hline & & 80 & $-3.28 \mathrm{E}+00$ & $2.33 \mathrm{E}+00$ & $1.31 \mathrm{E}+01$ & $5.06 \mathrm{E}-03$ & 72.9 & 144.6 \\
\hline & & 100 & $4.33 \mathrm{E}+00$ & $-2.83 \mathrm{E}+00$ & $4.93 \mathrm{E}+00$ & $2.64 \mathrm{E}-03$ & 43.6 & -33.1 \\
\hline \multirow[t]{11}{*}{ GC06A } & \multirow[t]{11}{*}{450} & 0 & $1.03 \mathrm{E}-01$ & $6.55 \mathrm{E}-01$ & $2.29 \mathrm{E}+01$ & $8.45 \mathrm{E}-03$ & 88.3 & 81.1 \\
\hline & & 5 & $1.13 \mathrm{E}-01$ & $7.15 \mathrm{E}-01$ & $1.88 \mathrm{E}+01$ & $6.93 \mathrm{E}-03$ & 87.8 & 81 \\
\hline & & 10 & $8.94 \mathrm{E}-02$ & $3.34 \mathrm{E}-01$ & $1.60 \mathrm{E}+01$ & $5.90 \mathrm{E}-03$ & 88.8 & 75 \\
\hline & & 15 & $-5.37 \mathrm{E}-02$ & $2.43 \mathrm{E}-01$ & $1.29 \mathrm{E}+01$ & 4.76E-03 & 88.9 & 102.5 \\
\hline & & 20 & $3.19 \mathrm{E}-01$ & $9.76 \mathrm{E}-02$ & $9.40 \mathrm{E}+00$ & $3.47 \mathrm{E}-03$ & 88 & 17 \\
\hline & & 30 & $1.48 \mathrm{E}-01$ & $-6.48 \mathrm{E}-01$ & $7.21 \mathrm{E}+00$ & $2.67 \mathrm{E}-03$ & 84.7 & -77.1 \\
\hline & & 40 & $-7.59 \mathrm{E}-01$ & $-1.36 \mathrm{E}+00$ & $5.84 \mathrm{E}+00$ & $2.23 \mathrm{E}-03$ & 75.1 & 240.8 \\
\hline & & 50 & $-7.65 \mathrm{E}-01$ & $-1.13 \mathrm{E}+00$ & $4.85 \mathrm{E}+00$ & $1.86 \mathrm{E}-03$ & 74.3 & 236 \\
\hline & & 65 & $4.60 \mathrm{E}-02$ & $-1.09 \mathrm{E}+00$ & $3.07 \mathrm{E}+00$ & $1.20 \mathrm{E}-03$ & 70.4 & -87.6 \\
\hline & & 80 & $-4.98 \mathrm{E}-01$ & $-1.19 \mathrm{E}+00$ & $2.81 \mathrm{E}+00$ & $1.14 \mathrm{E}-03$ & 65.4 & 247.2 \\
\hline & & 100 & $-2.04 \mathrm{E}-01$ & $-7.38 \mathrm{E}-01$ & $1.75 \mathrm{E}+00$ & 7.06E-04 & 66.4 & 254.5 \\
\hline \multirow[t]{11}{*}{ GC06B } & \multirow[t]{11}{*}{450} & 0 & $1.44 \mathrm{E}+00$ & $2.16 \mathrm{E}+00$ & $6.80 \mathrm{E}+01$ & $2.51 \mathrm{E}-02$ & 87.8 & 56.2 \\
\hline & & 5 & $1.17 \mathrm{E}+00$ & $2.32 \mathrm{E}+00$ & $5.78 \mathrm{E}+01$ & $2.14 \mathrm{E}-02$ & 87.4 & 63.2 \\
\hline & & 10 & $7.29 \mathrm{E}-01$ & $1.69 \mathrm{E}+00$ & $4.58 \mathrm{E}+01$ & $1.69 \mathrm{E}-02$ & 87.7 & 66.7 \\
\hline & & 15 & $-2.00 \mathrm{E}-01$ & $1.44 \mathrm{E}+00$ & $3.41 \mathrm{E}+01$ & $1.26 \mathrm{E}-02$ & 87.6 & 97.9 \\
\hline & & 20 & $-3.27 \mathrm{E}-01$ & $3.34 \mathrm{E}-01$ & $2.32 \mathrm{E}+01$ & $8.55 \mathrm{E}-03$ & 88.8 & 134.3 \\
\hline & & 30 & $2.25 \mathrm{E}-01$ & $-9.93 \mathrm{E}-01$ & $1.43 \mathrm{E}+01$ & $5.29 \mathrm{E}-03$ & 85.9 & -77.2 \\
\hline & & 40 & $-2.46 \mathrm{E}-01$ & $-3.76 \mathrm{E}-01$ & $1.04 \mathrm{E}+01$ & $3.84 \mathrm{E}-03$ & 87.5 & 236.8 \\
\hline & & 50 & $3.16 \mathrm{E}-01$ & $2.61 \mathrm{E}-01$ & $8.82 \mathrm{E}+00$ & $3.26 \mathrm{E}-03$ & 87.3 & 39.6 \\
\hline & & 65 & $-2.74 \mathrm{E}-01$ & $1.32 \mathrm{E}+00$ & $6.33 \mathrm{E}+00$ & $2.39 \mathrm{E}-03$ & 78 & 101.8 \\
\hline & & 80 & $-7.74 \mathrm{E}-01$ & $4.03 \mathrm{E}-01$ & $4.41 \mathrm{E}+00$ & $1.66 \mathrm{E}-03$ & 78.8 & 152.5 \\
\hline & & 100 & $-1.25 \mathrm{E}+00$ & $-1.02 \mathrm{E}+00$ & $3.69 \mathrm{E}+00$ & $1.49 \mathrm{E}-03$ & 66.3 & 219.1 \\
\hline \multirow[t]{11}{*}{ GC06C } & \multirow[t]{11}{*}{450} & 0 & $1.10 \mathrm{E}+01$ & $-1.59 \mathrm{E}+01$ & $4.08 \mathrm{E}+02$ & $1.51 \mathrm{E}-01$ & 87.3 & -55.2 \\
\hline & & 5 & $1.03 \mathrm{E}+01$ & $-1.51 \mathrm{E}+01$ & $3.77 \mathrm{E}+02$ & $1.39 \mathrm{E}-01$ & 87.2 & -55.7 \\
\hline & & 10 & $8.74 \mathrm{E}+00$ & $-1.31 \mathrm{E}+01$ & $3.12 \mathrm{E}+02$ & $1.15 \mathrm{E}-01$ & 87.1 & -56.2 \\
\hline & & 15 & $6.87 \mathrm{E}+00$ & $-1.03 \mathrm{E}+01$ & $2.46 \mathrm{E}+02$ & $9.08 \mathrm{E}-02$ & 87.1 & -56.3 \\
\hline & & 20 & $6.21 \mathrm{E}+00$ & $-8.30 \mathrm{E}+00$ & $1.92 \mathrm{E}+02$ & 7.10E-02 & 86.9 & -53.2 \\
\hline & & 30 & $3.91 \mathrm{E}+00$ & $-5.98 \mathrm{E}+00$ & $1.41 \mathrm{E}+02$ & $5.22 \mathrm{E}-02$ & 87.1 & -56.9 \\
\hline & & 40 & $3.45 \mathrm{E}+00$ & $-4.37 \mathrm{E}+00$ & $1.20 \mathrm{E}+02$ & 4.43E-02 & 87.3 & -51.7 \\
\hline & & 50 & $2.23 \mathrm{E}+00$ & $-5.28 \mathrm{E}+00$ & $1.04 \mathrm{E}+02$ & $3.84 \mathrm{E}-02$ & 86.8 & -67.1 \\
\hline & & 65 & $3.60 \mathrm{E}+00$ & $-3.34 \mathrm{E}+00$ & $8.36 \mathrm{E}+01$ & 3.09E-02 & 86.6 & -42.9 \\
\hline & & 80 & $2.45 \mathrm{E}+00$ & $-2.75 \mathrm{E}+00$ & $6.83 \mathrm{E}+01$ & $2.52 \mathrm{E}-02$ & 86.9 & -48.4 \\
\hline & & 100 & $1.60 \mathrm{E}+00$ & $-2.43 \mathrm{E}+00$ & $4.90 \mathrm{E}+01$ & $1.81 \mathrm{E}-02$ & 86.6 & -56.7 \\
\hline \multirow[t]{11}{*}{ GC06D } & \multirow[t]{11}{*}{450} & 0 & $1.95 \mathrm{E}+00$ & $-3.20 \mathrm{E}+01$ & $1.46 \mathrm{E}+03$ & $5.39 \mathrm{E}-01$ & 88.7 & -86.5 \\
\hline & & 5 & $8.42 \mathrm{E}+00$ & $-2.85 \mathrm{E}+01$ & $1.42 \mathrm{E}+03$ & $5.23 \mathrm{E}-01$ & 88.8 & -73.5 \\
\hline & & 10 & $7.56 \mathrm{E}+00$ & $-1.74 \mathrm{E}+01$ & $1.34 \mathrm{E}+03$ & $4.94 \mathrm{E}-01$ & 89.2 & -66.5 \\
\hline & & 15 & $6.71 \mathrm{E}+00$ & $-1.72 \mathrm{E}+01$ & $1.23 \mathrm{E}+03$ & $4.56 \mathrm{E}-01$ & 89.1 & -68.6 \\
\hline & & 20 & $7.35 \mathrm{E}+00$ & $-1.19 \mathrm{E}+01$ & $1.10 \mathrm{E}+03$ & $4.07 \mathrm{E}-01$ & 89.3 & -58.4 \\
\hline & & 30 & $4.48 \mathrm{E}+00$ & $-8.90 \mathrm{E}+00$ & $7.85 \mathrm{E}+02$ & $2.90 \mathrm{E}-01$ & 89.3 & -63.3 \\
\hline & & 40 & $1.87 \mathrm{E}+00$ & $-2.39 \mathrm{E}+00$ & $4.79 \mathrm{E}+02$ & $1.77 \mathrm{E}-01$ & 89.6 & -52 \\
\hline & & 50 & $1.12 \mathrm{E}-01$ & $2.93 \mathrm{E}+00$ & $2.39 \mathrm{E}+02$ & $8.82 \mathrm{E}-02$ & 89.3 & 87.8 \\
\hline & & 65 & $-4.26 \mathrm{E}+00$ & $7.07 \mathrm{E}+00$ & $8.35 \mathrm{E}+01$ & 3.10E-02 & 84.4 & 121.1 \\
\hline & & 80 & $5.45 \mathrm{E}+00$ & $1.24 \mathrm{E}+01$ & $3.89 \mathrm{E}+01$ & $1.52 \mathrm{E}-02$ & 70.8 & 66.3 \\
\hline & & 100 & $2.18 \mathrm{E}+01$ & $1.33 \mathrm{E}+01$ & $2.39 \mathrm{E}+01$ & $1.29 \mathrm{E}-02$ & 43.1 & 31.5 \\
\hline \multirow[t]{11}{*}{ GC06E } & 450 & 0 & $5.44 \mathrm{E}+02$ & $3.32 \mathrm{E}+02$ & $4.50 \mathrm{E}+03$ & $1.68 \mathrm{E}+00$ & 81.9 & 31.4 \\
\hline & & 5 & $5.35 \mathrm{E}+02$ & $3.32 \mathrm{E}+02$ & $4.44 \mathrm{E}+03$ & $1.65 \mathrm{E}+00$ & 81.9 & 31.9 \\
\hline & & 10 & $5.18 \mathrm{E}+02$ & $3.20 \mathrm{E}+02$ & $4.30 \mathrm{E}+03$ & $1.60 \mathrm{E}+00$ & 81.9 & 31.7 \\
\hline & & 15 & $4.92 \mathrm{E}+02$ & $3.02 \mathrm{E}+02$ & $4.07 \mathrm{E}+03$ & $1.52 \mathrm{E}+00$ & 81.9 & 31.6 \\
\hline & & 20 & $4.47 \mathrm{E}+02$ & $2.72 \mathrm{E}+02$ & $3.70 \mathrm{E}+03$ & $1.38 \mathrm{E}+00$ & 82 & 31.4 \\
\hline & & 30 & $3.04 \mathrm{E}+02$ & $1.87 \mathrm{E}+02$ & $2.60 \mathrm{E}+03$ & $9.69 \mathrm{E}-01$ & 82.2 & 31.6 \\
\hline & & 40 & $1.80 \mathrm{E}+02$ & $1.10 \mathrm{E}+02$ & $1.52 \mathrm{E}+03$ & $5.65 \mathrm{E}-01$ & 82.1 & 31.4 \\
\hline & & 50 & $9.53 \mathrm{E}+01$ & $7.04 \mathrm{E}+01$ & $7.14 \mathrm{E}+02$ & $2.67 \mathrm{E}-01$ & 80.6 & 36.5 \\
\hline & & 65 & $3.17 \mathrm{E}+01$ & $2.92 \mathrm{E}+01$ & $2.16 \mathrm{E}+02$ & $8.12 \mathrm{E}-02$ & 78.7 & 42.7 \\
\hline & & 80 & $-2.39 \mathrm{E}+01$ & $4.67 \mathrm{E}+01$ & $7.53 \mathrm{E}+01$ & 3.39E-02 & 55.1 & 117.2 \\
\hline & & 100 & $-1.47 \mathrm{E}+00$ & $3.15 \mathrm{E}+01$ & $2.74 \mathrm{E}+01$ & $1.54 \mathrm{E}-02$ & 41 & 92.7 \\
\hline
\end{tabular}




\begin{tabular}{|c|c|c|c|c|c|c|c|c|}
\hline Sample & $\begin{array}{l}\text { TCRM } \\
\left({ }^{\circ} \mathrm{C}\right)\end{array}$ & $\begin{array}{l}\text { Peak AF } \\
\text { field }(\mathrm{mT})\end{array}$ & $\begin{array}{l}\mathrm{X} \\
(\mathrm{mA} / \mathrm{m})\end{array}$ & $\begin{array}{l}\mathrm{Y} \\
(\mathrm{mA} / \mathrm{m})\end{array}$ & $\begin{array}{l}\mathrm{Z} \\
(\mathrm{mA} / \mathrm{m})\end{array}$ & $\begin{array}{l}\mathrm{J} \\
\left(\mathrm{mAm}^{2} / \mathrm{kg}\right)\end{array}$ & $\begin{array}{l}\text { Inc } \\
\left({ }^{\circ}\right)\end{array}$ & $\begin{array}{l}\text { Dec } \\
\left({ }^{\circ}\right)\end{array}$ \\
\hline \multirow[t]{11}{*}{ GC06F } & \multirow[t]{11}{*}{450} & 0 & $1.26 \mathrm{E}-01$ & $-1.50 \mathrm{E}-01$ & $4.28 \mathrm{E}+00$ & $1.58 \mathrm{E}+00$ & 87.4 & -49.9 \\
\hline & & 5 & $1.24 \mathrm{E}-01$ & $-1.38 \mathrm{E}-01$ & $4.23 \mathrm{E}+00$ & $1.56 \mathrm{E}+00$ & 87.5 & -48.2 \\
\hline & & 10 & $1.20 \mathrm{E}-01$ & $-1.41 \mathrm{E}-01$ & $4.08 \mathrm{E}+00$ & $1.51 \mathrm{E}+00$ & 87.4 & -49.5 \\
\hline & & 15 & $1.13 \mathrm{E}-01$ & $-1.31 \mathrm{E}-01$ & $3.84 \mathrm{E}+00$ & $1.42 \mathrm{E}+00$ & 87.4 & -49.2 \\
\hline & & 20 & $1.04 \mathrm{E}-01$ & $-1.15 \mathrm{E}-01$ & $3.49 \mathrm{E}+00$ & $1.29 \mathrm{E}+00$ & 87.5 & -48.1 \\
\hline & & 30 & $7.65 \mathrm{E}-02$ & $-8.82 \mathrm{E}-02$ & $2.54 \mathrm{E}+00$ & $9.39 \mathrm{E}-01$ & 87.4 & -49.1 \\
\hline & & 40 & $4.95 \mathrm{E}-02$ & $-4.89 \mathrm{E}-02$ & $1.56 \mathrm{E}+00$ & $5.77 \mathrm{E}-01$ & 87.4 & -44.6 \\
\hline & & 50 & $1.94 \mathrm{E}-02$ & $-2.07 \mathrm{E}-02$ & 7.32E-01 & $2.70 \mathrm{E}-01$ & 87.8 & -46.8 \\
\hline & & 65 & $1.96 \mathrm{E}-02$ & $6.00 \mathrm{E}-04$ & $1.95 \mathrm{E}-01$ & $7.23 \mathrm{E}-02$ & 84.3 & 1.8 \\
\hline & & 80 & $-1.14 \mathrm{E}-02$ & $-2.00 \mathrm{E}-04$ & $6.01 \mathrm{E}-02$ & $2.26 \mathrm{E}-02$ & 79.2 & 181.1 \\
\hline & & 100 & $2.22 \mathrm{E}-02$ & $1.32 \mathrm{E}-02$ & $1.53 \mathrm{E}-02$ & $1.11 \mathrm{E}-02$ & 30.6 & 30.7 \\
\hline \multirow[t]{11}{*}{ GC06G } & \multirow[t]{11}{*}{450} & 0 & $-1.45 \mathrm{E}+02$ & $-4.86 \mathrm{E}+02$ & $4.71 \mathrm{E}+03$ & $1.75 \mathrm{E}+00$ & 83.8 & 253.3 \\
\hline & & 5 & $-1.52 \mathrm{E}+02$ & $-5.06 \mathrm{E}+02$ & $4.68 \mathrm{E}+03$ & $1.74 \mathrm{E}+00$ & 83.6 & 253.3 \\
\hline & & 10 & $-1.46 \mathrm{E}+02$ & $-4.70 \mathrm{E}+02$ & $4.43 \mathrm{E}+03$ & $1.64 \mathrm{E}+00$ & 83.6 & 252.7 \\
\hline & & 15 & $-1.28 \mathrm{E}+02$ & $-4.05 \mathrm{E}+02$ & $3.85 \mathrm{E}+03$ & $1.43 \mathrm{E}+00$ & 83.7 & 252.5 \\
\hline & & 20 & $-9.75 \mathrm{E}+01$ & $-3.33 \mathrm{E}+02$ & $3.04 \mathrm{E}+03$ & $1.13 \mathrm{E}+00$ & 83.5 & 253.7 \\
\hline & & 30 & $-5.13 \mathrm{E}+01$ & $-1.74 \mathrm{E}+02$ & $1.56 \mathrm{E}+03$ & $5.80 \mathrm{E}-01$ & 83.4 & 253.6 \\
\hline & & 40 & $-2.85 \mathrm{E}+01$ & $-9.26 \mathrm{E}+01$ & $7.69 \mathrm{E}+02$ & $2.86 \mathrm{E}-01$ & 82.8 & 252.9 \\
\hline & & 50 & $-2.09 \mathrm{E}+01$ & $-3.68 \mathrm{E}+01$ & $3.61 \mathrm{E}+02$ & $1.34 \mathrm{E}-01$ & 83.3 & 240.4 \\
\hline & & 65 & $-1.35 \mathrm{E}+01$ & $-2.20 \mathrm{E}+01$ & $1.32 \mathrm{E}+02$ & $4.96 \mathrm{E}-02$ & 78.9 & 238.5 \\
\hline & & 80 & $-8.31 \mathrm{E}+00$ & $-3.19 \mathrm{E}+00$ & $5.66 \mathrm{E}+01$ & $2.11 \mathrm{E}-02$ & 81.1 & 201 \\
\hline & & 100 & $3.47 \mathrm{E}+00$ & $2.73 \mathrm{E}+00$ & $1.97 \mathrm{E}+01$ & $7.46 \mathrm{E}-03$ & 77.4 & 38.2 \\
\hline \multirow[t]{11}{*}{ GC06A } & \multirow[t]{11}{*}{600} & 0 & $-4.28 \mathrm{E}-02$ & $2.83 \mathrm{E}-01$ & $9.27 \mathrm{E}+00$ & $3.42 \mathrm{E}-03$ & 88.2 & 98.6 \\
\hline & & 5 & $-5.31 \mathrm{E}-02$ & $2.68 \mathrm{E}-01$ & $9.14 \mathrm{E}+00$ & $3.37 \mathrm{E}-03$ & 88.3 & 101.2 \\
\hline & & 10 & $-1.25 \mathrm{E}-02$ & $2.16 \mathrm{E}-01$ & $8.54 \mathrm{E}+00$ & $3.15 \mathrm{E}-03$ & 88.5 & 93.3 \\
\hline & & 15 & $-2.70 \mathrm{E}-03$ & $1.82 \mathrm{E}-01$ & $7.72 \mathrm{E}+00$ & $2.85 \mathrm{E}-03$ & 88.6 & 90.8 \\
\hline & & 20 & $-6.20 \mathrm{E}-03$ & $1.99 \mathrm{E}-01$ & $6.86 \mathrm{E}+00$ & $2.53 \mathrm{E}-03$ & 88.3 & 91.8 \\
\hline & & 30 & $-6.10 \mathrm{E}-03$ & $5.87 \mathrm{E}-02$ & $5.37 \mathrm{E}+00$ & $1.98 \mathrm{E}-03$ & 89.4 & 95.9 \\
\hline & & 40 & $-3.99 \mathrm{E}-02$ & $6.86 \mathrm{E}-02$ & $4.18 \mathrm{E}+00$ & $1.54 \mathrm{E}-03$ & 88.9 & 120.2 \\
\hline & & 50 & $-5.51 \mathrm{E}-02$ & $1.83 \mathrm{E}-02$ & $3.08 \mathrm{E}+00$ & $1.14 \mathrm{E}-03$ & 88.9 & 161.7 \\
\hline & & 65 & $-2.08 \mathrm{E}-02$ & $-1.47 \mathrm{E}-02$ & $2.07 \mathrm{E}+00$ & 7.63E-04 & 89.3 & 215.2 \\
\hline & & 80 & $-6.73 \mathrm{E}-02$ & $-4.70 \mathrm{E}-02$ & $1.52 \mathrm{E}+00$ & $5.61 \mathrm{E}-04$ & 86.9 & 214.9 \\
\hline & & 100 & $-2.02 \mathrm{E}-02$ & $-6.82 \mathrm{E}-02$ & $-1.10 \mathrm{E}+00$ & $4.08 \mathrm{E}-04$ & -86.3 & 253.5 \\
\hline \multirow[t]{11}{*}{ GC06B } & \multirow[t]{11}{*}{600} & 0 & $2.46 \mathrm{E}-01$ & $4.87 \mathrm{E}-01$ & $1.71 \mathrm{E}+01$ & $6.31 \mathrm{E}-03$ & 88.2 & 63.2 \\
\hline & & 5 & $2.32 \mathrm{E}-01$ & $5.24 \mathrm{E}-01$ & $1.67 \mathrm{E}+01$ & $6.17 \mathrm{E}-03$ & 88 & 66.1 \\
\hline & & 10 & $2.05 \mathrm{E}-01$ & $4.18 \mathrm{E}-01$ & $1.51 \mathrm{E}+01$ & $5.56 \mathrm{E}-03$ & 88.2 & 63.9 \\
\hline & & 15 & $2.77 \mathrm{E}-01$ & $2.86 \mathrm{E}-01$ & $1.30 \mathrm{E}+01$ & $4.80 \mathrm{E}-03$ & 88.2 & 45.9 \\
\hline & & 20 & $3.04 \mathrm{E}-01$ & $1.57 \mathrm{E}-01$ & $1.10 \mathrm{E}+01$ & $4.05 \mathrm{E}-03$ & 88.2 & 27.4 \\
\hline & & 30 & $2.03 \mathrm{E}-01$ & $2.59 \mathrm{E}-01$ & $8.38 \mathrm{E}+00$ & $3.09 \mathrm{E}-03$ & 87.8 & 51.8 \\
\hline & & 40 & $5.97 \mathrm{E}-02$ & $1.32 \mathrm{E}-01$ & $6.75 \mathrm{E}+00$ & $2.49 \mathrm{E}-03$ & 88.8 & 65.7 \\
\hline & & 50 & $5.90 \mathrm{E}-02$ & $1.22 \mathrm{E}-01$ & $5.31 \mathrm{E}+00$ & $1.96 \mathrm{E}-03$ & 88.5 & 64.3 \\
\hline & & 65 & $1.21 \mathrm{E}-01$ & $1.03 \mathrm{E}-01$ & $3.83 \mathrm{E}+00$ & $1.41 \mathrm{E}-03$ & 87.6 & 40.5 \\
\hline & & 80 & 3.79E-02 & $8.51 \mathrm{E}-02$ & $2.99 \mathrm{E}+00$ & $1.10 \mathrm{E}-03$ & 88.2 & 66 \\
\hline & & 100 & $8.76 \mathrm{E}-02$ & $-4.18 \mathrm{E}-02$ & $-9.95 \mathrm{E}-01$ & $3.69 \mathrm{E}-04$ & -84.4 & -25.5 \\
\hline \multirow[t]{11}{*}{ GC06C } & \multirow[t]{11}{*}{600} & 0 & $-1.77 \mathrm{E}+01$ & $2.64 \mathrm{E}+01$ & $5.88 \mathrm{E}+02$ & $2.17 \mathrm{E}-01$ & 86.9 & 123.9 \\
\hline & & 5 & $-1.74 \mathrm{E}+01$ & $2.59 \mathrm{E}+01$ & $5.75 \mathrm{E}+02$ & $2.12 \mathrm{E}-01$ & 86.9 & 123.8 \\
\hline & & 10 & $-1.55 \mathrm{E}+01$ & $2.35 \mathrm{E}+01$ & $5.22 \mathrm{E}+02$ & $1.93 \mathrm{E}-01$ & 86.9 & 123.4 \\
\hline & & 15 & $-1.35 \mathrm{E}+01$ & $2.06 \mathrm{E}+01$ & $4.57 \mathrm{E}+02$ & $1.69 \mathrm{E}-01$ & 86.9 & 123.3 \\
\hline & & 20 & $-1.13 \mathrm{E}+01$ & $1.74 \mathrm{E}+01$ & $3.89 \mathrm{E}+02$ & $1.44 \mathrm{E}-01$ & 86.9 & 123.1 \\
\hline & & 30 & $-8.61 \mathrm{E}+00$ & $1.30 \mathrm{E}+01$ & $2.90 \mathrm{E}+02$ & $1.07 \mathrm{E}-01$ & 86.9 & 123.6 \\
\hline & & 40 & $-6.93 \mathrm{E}+00$ & $1.11 \mathrm{E}+01$ & $2.46 \mathrm{E}+02$ & $9.11 \mathrm{E}-02$ & 87 & 121.9 \\
\hline & & 50 & $-6.64 \mathrm{E}+00$ & $9.74 \mathrm{E}+00$ & $2.19 \mathrm{E}+02$ & $8.10 \mathrm{E}-02$ & 86.9 & 124.3 \\
\hline & & 65 & $-5.38 \mathrm{E}+00$ & $8.51 \mathrm{E}+00$ & $1.86 \mathrm{E}+02$ & $6.89 \mathrm{E}-02$ & 86.9 & 122.3 \\
\hline & & 80 & $-3.14 \mathrm{E}+00$ & $7.08 \mathrm{E}+00$ & $1.57 \mathrm{E}+02$ & $5.81 \mathrm{E}-02$ & 87.2 & 114 \\
\hline & & 100 & $-2.52 \mathrm{E}+00$ & $5.60 \mathrm{E}+00$ & $1.18 \mathrm{E}+02$ & $4.36 \mathrm{E}-02$ & 87 & 114.2 \\
\hline \multirow[t]{11}{*}{ GC06D } & 600 & 0 & $7.33 \mathrm{E}+01$ & $3.53 \mathrm{E}+02$ & $8.78 \mathrm{E}+03$ & $3.24 \mathrm{E}+00$ & 87.6 & 78.3 \\
\hline & & 5 & $7.53 \mathrm{E}+01$ & $3.68 \mathrm{E}+02$ & $8.64 \mathrm{E}+03$ & $3.19 \mathrm{E}+00$ & 87.5 & 78.4 \\
\hline & & 10 & $7.81 \mathrm{E}+01$ & $3.60 \mathrm{E}+02$ & $8.19 \mathrm{E}+03$ & $3.03 \mathrm{E}+00$ & 87.4 & 77.8 \\
\hline & & 15 & $6.01 \mathrm{E}+01$ & $2.96 \mathrm{E}+02$ & $7.50 \mathrm{E}+03$ & $2.77 \mathrm{E}+00$ & 87.7 & 78.5 \\
\hline & & 20 & $5.95 \mathrm{E}+01$ & $2.46 \mathrm{E}+02$ & $6.42 \mathrm{E}+03$ & $2.37 \mathrm{E}+00$ & 87.7 & 76.4 \\
\hline & & 30 & $4.10 \mathrm{E}+01$ & $1.55 \mathrm{E}+02$ & $3.97 \mathrm{E}+03$ & $1.47 \mathrm{E}+00$ & 87.7 & 75.2 \\
\hline & & 40 & $2.29 \mathrm{E}+01$ & $8.86 \mathrm{E}+01$ & $2.34 \mathrm{E}+03$ & $8.62 \mathrm{E}-01$ & 87.8 & 75.5 \\
\hline & & 50 & $1.27 \mathrm{E}+01$ & $6.83 \mathrm{E}+01$ & $1.42 \mathrm{E}+03$ & $5.25 \mathrm{E}-01$ & 87.2 & 79.5 \\
\hline & & 65 & $7.48 \mathrm{E}+00$ & $3.96 \mathrm{E}+01$ & $8.68 \mathrm{E}+02$ & $3.21 \mathrm{E}-01$ & 87.3 & 79.3 \\
\hline & & 80 & $4.91 \mathrm{E}+00$ & $1.32 \mathrm{E}+01$ & $6.35 \mathrm{E}+02$ & $2.35 \mathrm{E}-01$ & 88.7 & 69.6 \\
\hline & & 100 & $3.24 \mathrm{E}+00$ & $3.04 \mathrm{E}+01$ & $4.87 \mathrm{E}+02$ & $1.80 \mathrm{E}-01$ & 86.4 & 83.9 \\
\hline
\end{tabular}




\begin{tabular}{lllllllll}
\hline Sample & $\begin{array}{l}\text { TCRM } \\
\left({ }^{\circ} \mathrm{C}\right)\end{array}$ & $\begin{array}{l}\text { Peak AF } \\
\text { field }(\mathrm{mT})\end{array}$ & $\begin{array}{l}\mathrm{X} \\
(\mathrm{mA} / \mathrm{m})\end{array}$ & $\begin{array}{l}\mathrm{Y} \\
(\mathrm{mA} / \mathrm{m})\end{array}$ & $\begin{array}{l}\mathrm{Z} \\
(\mathrm{mA} / \mathrm{m})\end{array}$ & $\begin{array}{l}\mathrm{J} \\
(\mathrm{mAm} / \mathrm{kg})\end{array}$ & $\begin{array}{l}\text { Inc } \\
\left({ }^{\circ}\right)\end{array}$ & $\begin{array}{l}\text { Dec } \\
\left({ }^{\circ}\right)\end{array}$ \\
\hline GC06E & 600 & 0 & $-4.97 \mathrm{E}-01$ & $1.41 \mathrm{E}+00$ & $4.83 \mathrm{E}+01$ & $1.78 \mathrm{E}+01$ & 88.2 & 109.5 \\
& & 5 & $-4.92 \mathrm{E}-01$ & $1.39 \mathrm{E}+00$ & $4.81 \mathrm{E}+01$ & $1.78 \mathrm{E}+01$ & 88.2 & 109.5 \\
& & 10 & $-4.93 \mathrm{E}-01$ & $1.37 \mathrm{E}+00$ & $4.76 \mathrm{E}+01$ & $1.76 \mathrm{E}+01$ & 88.2 & 109.8 \\
& & 15 & $-4.89 \mathrm{E}-01$ & $1.31 \mathrm{E}+00$ & $4.63 \mathrm{E}+01$ & $1.71 \mathrm{E}+01$ & 88.3 & 110.6 \\
& & 20 & $-4.48 \mathrm{E}-01$ & $1.22 \mathrm{E}+00$ & $4.39 \mathrm{E}+01$ & $1.62 \mathrm{E}+01$ & 88.3 & 110.2 \\
& & 30 & $-3.82 \mathrm{E}-01$ & $9.60 \mathrm{E}-01$ & $3.60 \mathrm{E}+01$ & $1.33 \mathrm{E}+01$ & 88.4 & 111.7 \\
& & 40 & $-2.88 \mathrm{E}-01$ & $7.00 \mathrm{E}-01$ & $2.73 \mathrm{E}+01$ & $1.01 \mathrm{E}+01$ & 88.4 & 112.3 \\
& & 50 & $-1.93 \mathrm{E}-01$ & $4.71 \mathrm{E}-01$ & $1.83 \mathrm{E}+01$ & $6.75 \mathrm{E}+00$ & 88.4 & 112.3 \\
& & 65 & $-6.63 \mathrm{E}-02$ & $2.47 \mathrm{E}-01$ & $9.03 \mathrm{E}+00$ & $3.33 \mathrm{E}+00$ & 88.4 & 105 \\
$\mathrm{GC06G}$ & 80 & $-3.99 \mathrm{E}-02$ & $1.23 \mathrm{E}-01$ & $4.16 \mathrm{E}+00$ & $1.54 \mathrm{E}+00$ & 88.2 & 107.9 \\
& & 100 & $4.70 \mathrm{E}-03$ & $6.08 \mathrm{E}-02$ & $1.39 \mathrm{E}+00$ & $5.13 \mathrm{E}-01$ & 87.5 & 85.6 \\
& 0 & $4.84 \mathrm{E}+02$ & $-2.54 \mathrm{E}+02$ & $7.90 \mathrm{E}+03$ & $2.92 \mathrm{E}+00$ & 86 & -27.7 \\
& 5 & $6.10 \mathrm{E}+02$ & $-3.21 \mathrm{E}+02$ & $7.88 \mathrm{E}+03$ & $2.92 \mathrm{E}+00$ & 85 & -27.8 \\
& 10 & $6.15 \mathrm{E}+02$ & $-3.36 \mathrm{E}+02$ & $7.77 \mathrm{E}+03$ & $2.88 \mathrm{E}+00$ & 84.8 & -28.7 \\
& 15 & $6.02 \mathrm{E}+02$ & $-3.33 \mathrm{E}+02$ & $7.49 \mathrm{E}+03$ & $2.78 \mathrm{E}+00$ & 84.8 & -29 \\
& 20 & $5.65 \mathrm{E}+02$ & $-3.16 \mathrm{E}+02$ & $7.01 \mathrm{E}+03$ & $2.60 \mathrm{E}+00$ & 84.7 & -29.2 \\
& 30 & $4.58 \mathrm{E}+02$ & $-2.37 \mathrm{E}+02$ & $5.62 \mathrm{E}+03$ & $2.08 \mathrm{E}+00$ & 84.8 & -27.4 \\
& & $3.54 \mathrm{E}+02$ & $-1.84 \mathrm{E}+02$ & $4.32 \mathrm{E}+03$ & $1.60 \mathrm{E}+00$ & 84.7 & -27.5 \\
& & 40 & $2.57 \mathrm{E}+02$ & $-1.23 \mathrm{E}+02$ & $3.10 \mathrm{E}+03$ & $1.15 \mathrm{E}+00$ & 84.8 & -25.5 \\
& 50 & $1.52 \mathrm{E}+02$ & $-7.17 \mathrm{E}+01$ & $1.79 \mathrm{E}+03$ & $6.65 \mathrm{E}-01$ & 84.7 & -25.3 \\
& 65 & $8.72 \mathrm{E}+01$ & $-3.64 \mathrm{E}+01$ & $1.03 \mathrm{E}+03$ & $3.81 \mathrm{E}-01$ & 84.8 & -22.6 \\
& 80 & $3.83 \mathrm{E}+01$ & $-1.09 \mathrm{E}+01$ & $5.10 \mathrm{E}+02$ & $1.89 \mathrm{E}-01$ & 85.5 & -15.9 \\
\hline
\end{tabular}

